
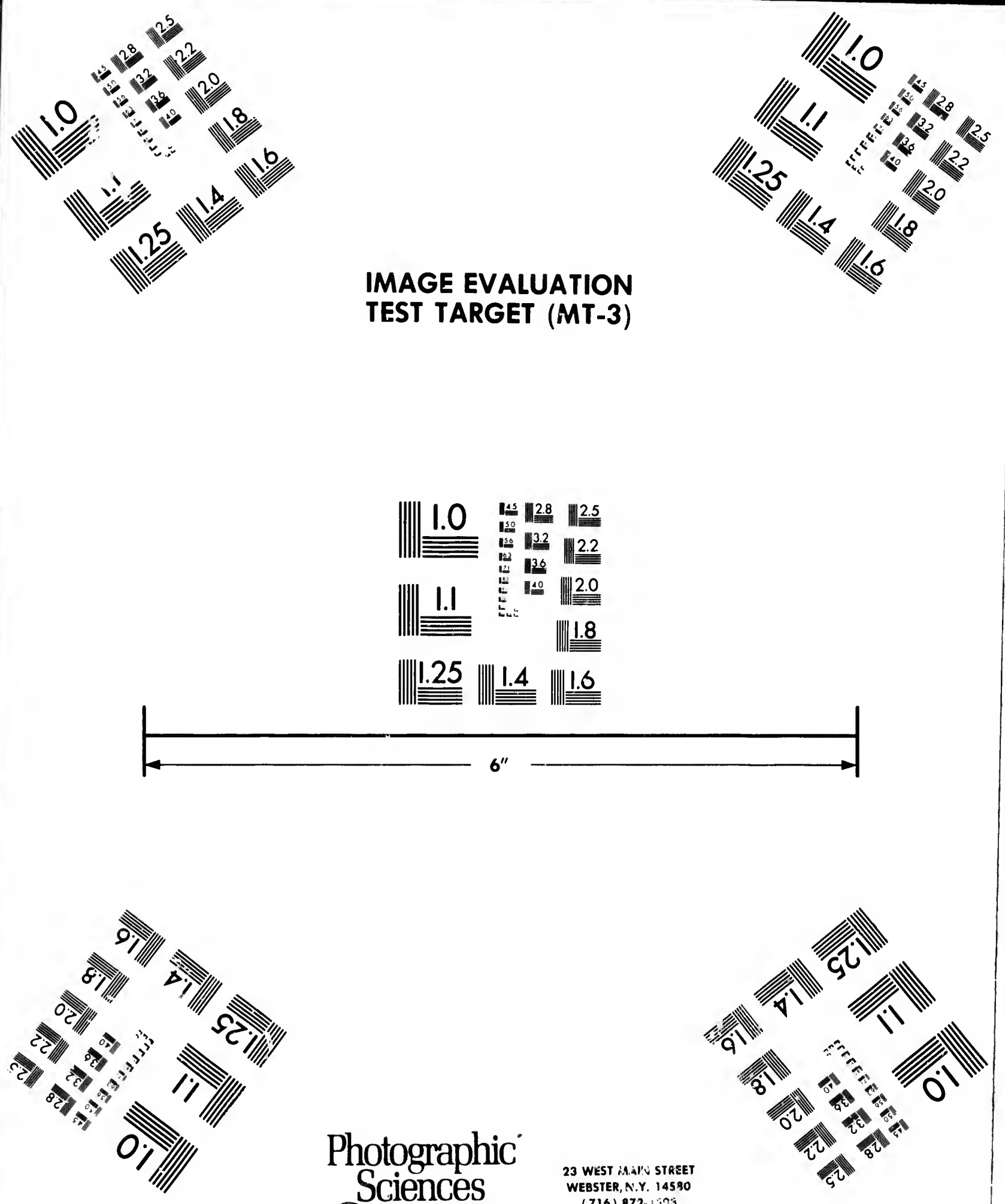

Photographic

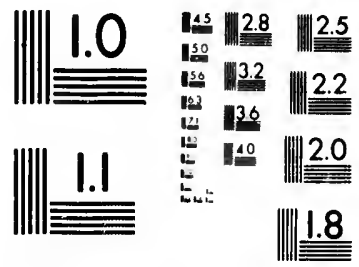

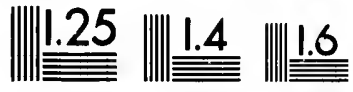

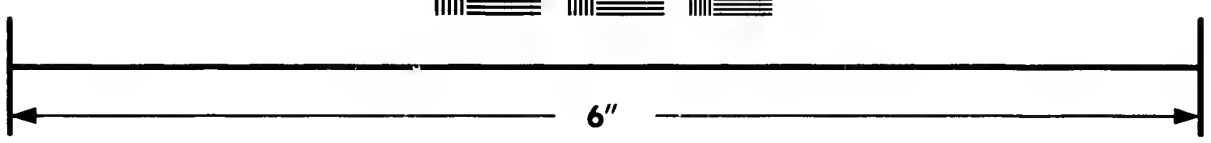

$p$

Sciences

Corporation
23 WEST MAAL'U STREET WEBSTER, N.Y. 14580 (716) 872 +155

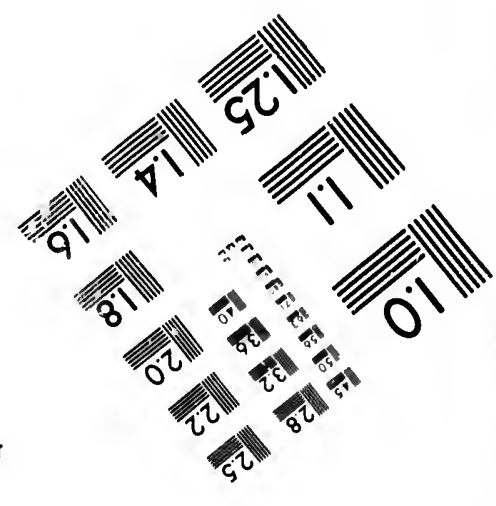




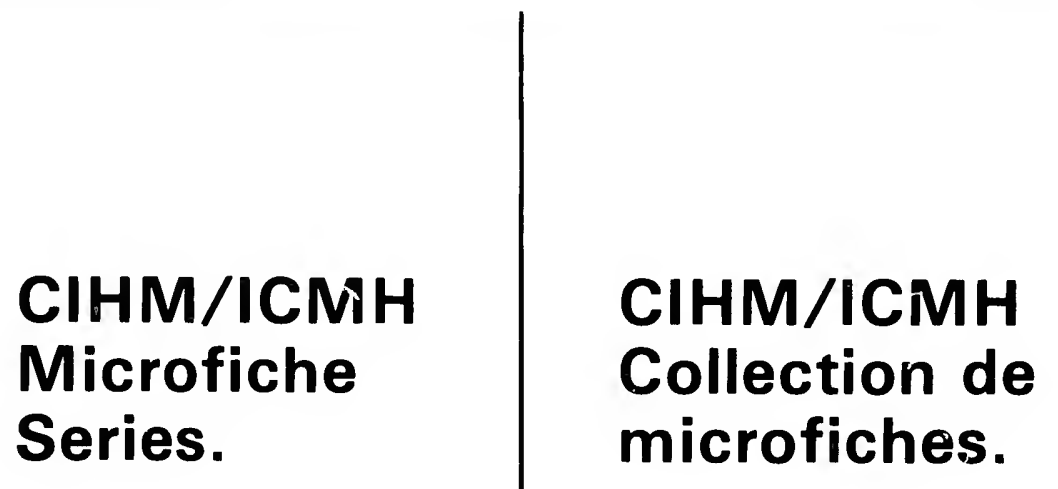

Canadian Institute for Historical Microreproductions / Institut canadien de microreproductions historiques
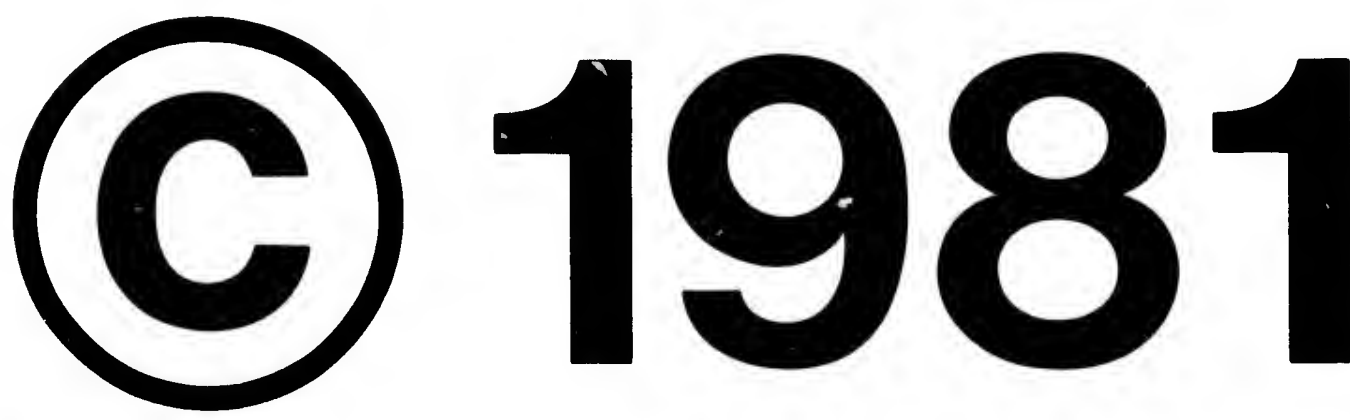
The Institute has sttempted to obtain the best original copy available for filming. Features of this copy which may be blbliographically unique, which may alter any of the images in the reproduction, or which may significantly change the usual method of filming, are checked below.

Coloured covers/

Couverture de couleur

Covers damaged/

Couverture endommagée

Covers restored and/or laminated/

Couverture restaurée et/ou pelliculée

Cover title missing/

Le titre de couverture manque

Coloured maps/

Cartes géographiques en couleur

Coloured ink (i.e. other than blue or black)/

Encre de couleur (i.e. autre que bleue ou noira)

Coloured plates and/or illustrations/

Planches et/ou illustrations en couleur

Bound with other material/

Relié avec d'autres documents

Tight binding may cause shodows or distortion along interior margin/

La reliure serrée peut causer de l'ombre ou de la distortion le long de la marge intérieure

Blank leaves added during restoration may appear within the text. Whenever possible, these have been omltted from filming/

II se peut que certaines pages blanches ajout6es lors d'une restauration apparaissent dans le texte, mais, lorsque cela était possible, ces pages n'ont pas été filmbes.

Additicnal comments:/

Commentaires supplémentaires:
L'Institut a microfilmé le meilleur exemplaire qu'il lui a été possible de 80 procurer. Les détails de cet exemplaire qui sont peut-atre uniques du polnt de vue bibliogrephique, qui peuvent modifier une image reproduite, ou qui peuvent exiger une modification dans la méthode normale de filmage sont indiqués ci-dessous.

Coloured pages/

Pages de coulour

Pages damaged/

Pages endominagées

Pages restored and/or laminated/

Pages restaurées et/ou pelliculées

Pages discoloured, stained or foxed/

Pages décolorées, tachetées ou piquées

\section{Pages detached/}

Pages dótachéas

\section{Showthrough/}

Transparence

Quality of print varies/

Quaiité inégale de l'impression

Includes supplementary material/

Comprend du matériel supplémentaire

Only edition available/

Seule édition disponible

Pages wholly or partially obscured by errata slips, tissues, etc., have been refilmed to ensure the best possible image/ Les pages totalement ou partiellement obscurcies par un feuillet d'errate, une pelure, etc., ont été filmées a nouveau de façon á obtenir la meilleure image possible.

This item is filmed at the reduction ratio checked below/

Ce document est filmé au taux de réductlon indiqué ci-dessous.

$10 \mathrm{X}$

$14 \times$

$18 x$

$22 x$

$26 x$

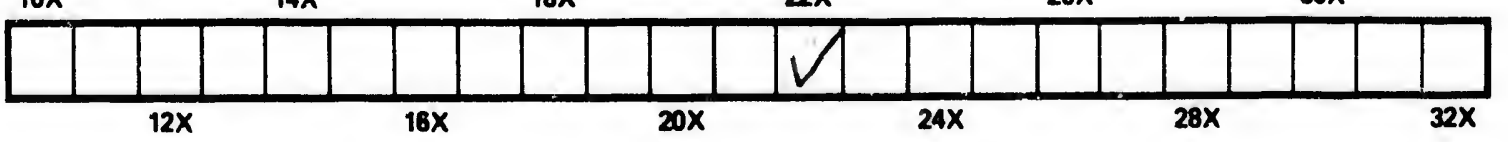


The copy filmed here has been reproduced thenks to the generosity of:

\author{
Library Division \\ Provincial Archives of British Columbia
}

The images appearing here are the best quallty possible considering the condition and legibillty of the original copy and in keeping with the filming contract specifications.

Original copies in printed paper covers are fllmed beginning with the front cover and ending on the last page with a printed or illustrated impres. sion, or the back cover when appropriate. All other original copies are filmed beginning on the first page with a printed or illustrated impression, and ending on the last pege with a printed or illustrated impression.

The last recorded frame on each microfiche shall contain the symbol $\rightarrow$ (meaning "CON. TINUED"), or the symbol $\nabla$ (meaning "END"). whichever applios.

Maps, plates, cherts, etc., may be filmed at different reduction ratios. Those too large to be entirely included in one exposure are filmed beginning in the upper left hand corner, left to right and top to bottom, as many frames as required. The following diegrams illustrate the method:
L'exemplaire filmó fut reproduit grace à la góndrosité de:

Library Division

Provincial Archives of British Columbia

Les images suivantes ont bto reproduites avec le plus grand soin, compte tenu de la condition et de la netteté de l'exemplaire filmb, et en conformitb avec les conditions du contrat do filmage.

Les exemplaires origineux dont la couverture en papier est imprimbe sont filmés en commencant par le premier plat et en terminant soit par la dernibre page qui comporte une empreinte d'impression ou d'illustration, soit par le second plat, selon le cas. Tous les autres exemplaires originaux sont filmés en commençant par la premiere page qui comporte une empreinte d'impression ou d'illustration et en terminant par le dernitre page qui comporte une telle empreinte.

Un des symboles suivants appareitra sur la derniere image de chaque microfiche, selon le cas: le symbole $\longrightarrow$ signifie "A SUIVRE", le symbole $\nabla$ signifie "FIN".

Les cartes, planches, tebleaux, etc.. peuvent être filmés a des taux de réduction differents. Lorsque le document est trop grand pour etre reproduit en un seul cliche, il est filmé à pertir de l'angle supérieur gauche, de gauche a droite. et de haut en bas, en prenent le nombre d'imeges nécessaire. Les diegrammes suivents illustrent la méthode.

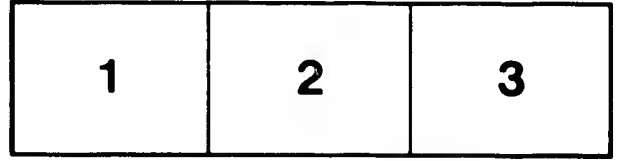

\begin{tabular}{|l|l|l|}
\hline 1 & 2 & 3 \\
\hline 4 & 5 & 6 \\
\hline
\end{tabular}

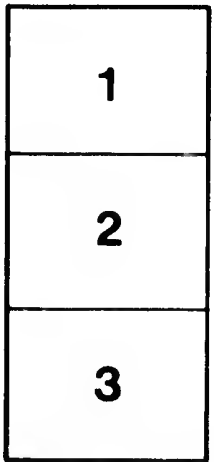




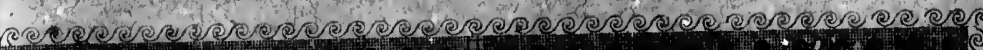

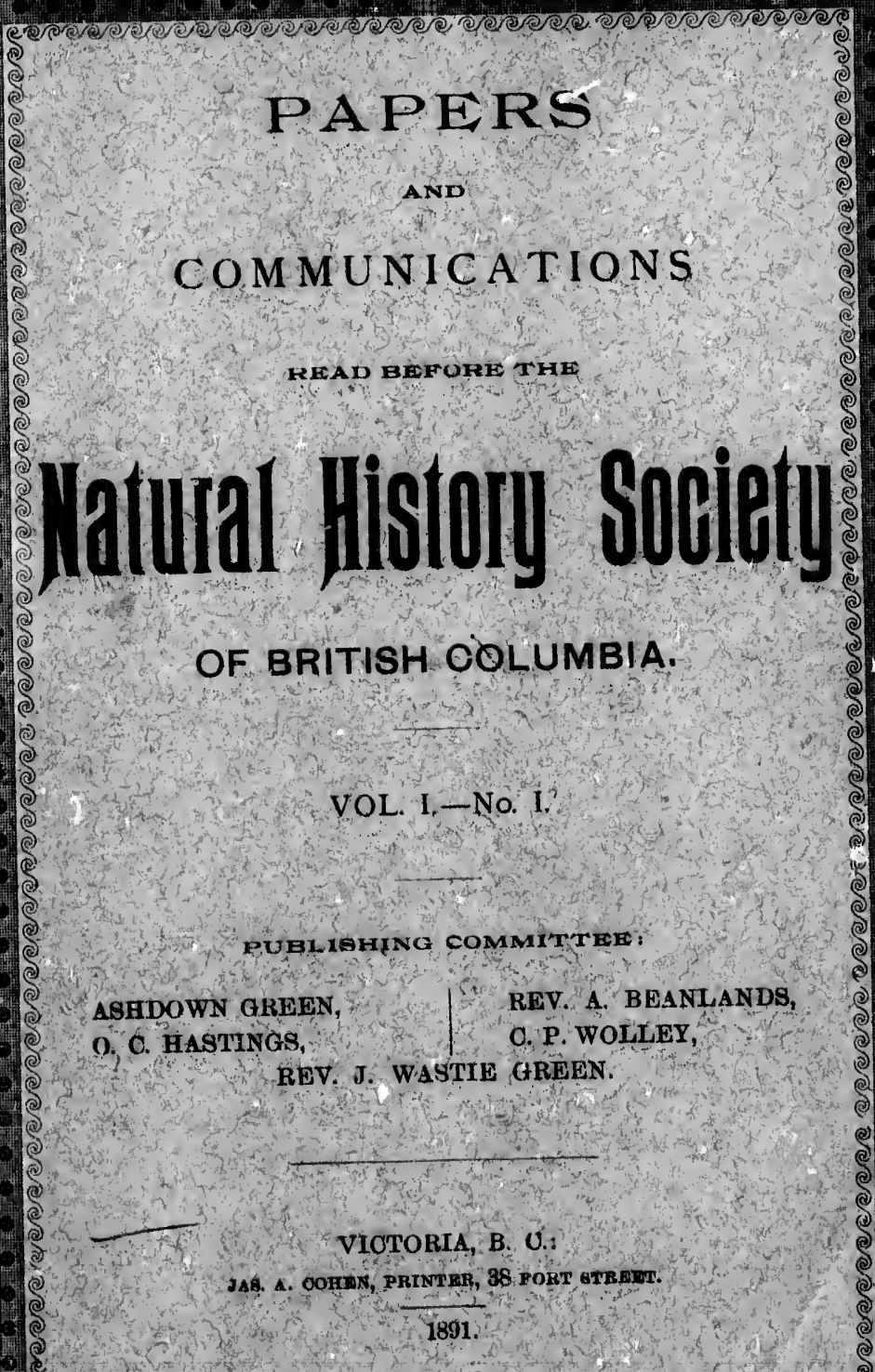

(a) e 


\section{P A P E RS}

AND

\section{COMMUNICATIONS}

READ GEFORE THE

Natulal Historly Sobjetly

OF BRITISH COLUMBIA.

VOL. I.-No. I.

PUBLIפHING COMMITTEE:

ASHDOWN GREEN,

o. C. hastings,

REV. A. BEANLANDS,

O. P. WOLLEY,

REV. J. WASTIE GREEN.

VICTORIA, B. O.:

JAB. A. COHEN, PRINTER, 38 FORT STRERT.

1891. 


\section{NW \\ q7)1.25 \\ $N 285 \mathrm{p}$}

befo the

kno in $t$ it $w$ title that pro of $t$ the

and Gre Sec $\mathrm{Cu}$

J.

the $\mathrm{Mr}$ to the 


\section{ANNUAL: REgPORT.}

To the Mcn.bcrs of the Natural History Sociely of B. C.:

Your Committee, elected twelve months ago, beg to lay before you a report of the transactions during the first year of the Society's existence.

At a meeting, notice of which was sent to gentlemen known to be interested in the study of Natural History, held in the office of the Provincial Museum, on March 26th, I89o, it was decided that a Society should be organised bearing the title of the Natural History Society of British Columbia, and that the object or this Society should be to acquire and promote a more extended knor ledge of the natural history of the Province, and to act as an independent auxiliary to the Provincial Museum.

Rules and by-laws were adopted at the sarie meeting, and the following officers appointed:-President, Ashdown Green, C. E.; Vice-Presidents, M. Lopatecki and Dr. Hasell; Secretary, Dr. C. F. Newcombe; Treasurer, J. K. Worsfold; Curator and Librarian, John Fannin; Committee, J Deans, J. Fielding, Capt. Devereux, H. Wootton.

More than forty gentlemen signified their wish to join the Society.

At Mr. Fannin's suggestion, a committee, consisting of Mr. A. Green, Dr. Hasell and Dr. Newcombe, was ajpointed to wait upon the Provincial Secretary, to ask permission for the Society to hold fortnightly meetings in one of the rooms 
attached to the Provincial Museum. This Committee reported at the next meeting, on March 3 Ist, that they had a very favorable reception, and that their request was at once granted.

The first regular meeting of the Society, thus sucessfully started, was held on April 14th, when our President delivered his inaugural address and then read the first instalment of a paper on the Salmonida of British Columbia.

The following are the Titles of the remainder of the papers read during the the year:

Monday, April 28th,- "The Study of Entomology."

Monday, May 12th,-Mr. A. Green, "Salmonida of B. C. (concluded.)

Niay, 2oth,-Dr. Hasell, "Birds, What They Are."

June 9th,-Mr. J. Deans, - "The Preservation of the Indian Remains of B. C."

June 3oth,-Rev'd P. Jenns, "Leaves."

July, 14th,-Rev'd A. Beanlands, "The Jade Implements of B. C."

July 28 th,-Mr. J. Fannin, "The Birds of B. C. and their Distribution."

Aug. 25th,-Dr. Boas, "The Skulls of the Indian Tribes of B. C."

Sept. 8th,-Mr. J. Deans, "The Haidah Legend of the Mountain Goat."

October,-Dr. Newcombe, "The Crabs of B. C."

Nov. 3rd.-Mr. J. Deans, "Certain Myths of the Queen Charlotte Islanders.

Nov. I 7 th,-Dr. Hasell, "Account of a Recent Visit to Provincial Museums in England."

Dec. Ist,-Dr. Hasell, "Lowest Forms of Animal and Vegetable Life."

Dec. 2gth,-Mr. J. Deans, "Topography and Resources of the Queen Charlotte Islands." 
eported

a very ranted.

cssfully It delivment of

of the

ogy."

nida of

re."

of the

Implc-

C. and

n Tribes

$d$ of the

e Queen

Visit to

mal and

Resources
Jan. 12 th, $189 \mathrm{I},-\mathrm{Mr}$. C. P. Wolley " Bears."

Van. 26th,-Mr. A. Green, "The Economic Fishes of B. C.

$\checkmark F$ eb $9^{\text {th, }}$-Mr. Danby, "The Study of Entomology."

Mar. 9th, Mr. J. Fannin, "The Deer of B. C.

Mar. 23 rd,-Mr. A. L. Poudrier, "The Mineral Resources of the Chilcotin Country.

During the spring and summer months the following ficld excursions took place: On April 12th to Cadboro Bay; April 26th to McCaulay's Point; May roth, Gold. stream; June IIth, Cadboro Bay; June 28th, Aldermere, where the Club enjoyed the hospitality of Dr. and Mrs.

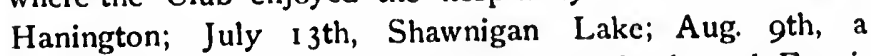
dredging excursion off Victoria, Trial Islands and Esquimalt; Aug. 23rd, Beaver Lakes; September 6th, dredging excursion off Sidney and James Islands; Sept. 20th, Lagoon, Esquimalt.

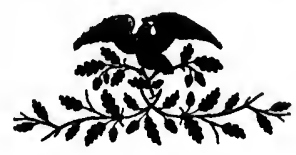



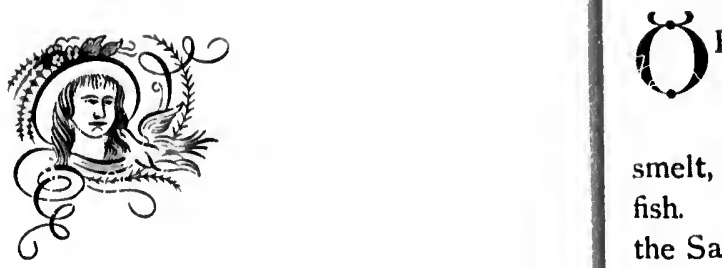

smelt, fish. the Sa to ther the lar view, Oncor his no: the sai easter perhas readily anal $f i$ the $S c$ rather wrote namec they a specie correc differe 


\section{$\checkmark$ THE SALMONIDAE}

\section{OIr- \\ British Columbia.}

$\int^{2} \mathrm{~F}$

F the 13 genera of the Salmonida known in North America, nine are represented within the limits of this Province. These embrace the capelin, oolachan, smelt, surf-smelt, salmon, trout, charr, grayling, and whitefish. Beyond nuting the fact that the first four belong to the Salmonidx of our waters, I do not again propose to refer to them, but will commence with a description of our salmon, the largest and most valuable from an economic point of view, of the family. The generic name of our salmon is Oncorhynchus, or hook-nose. Why this personal reference to his nose should have been made I do not know, seeing that the samc prominence of feature is shared by the male of the eastern salmon and trout during the breeding season, though perhaps, in a less marked degree. This geniss may be readily distinguished from that of Salmo by the length of tive anal fin, the rays of which number from 13-16 rays, whereas the Salmo, that is the trout, and charr, have but $9-11$. It is rather a curious fact that a Russian, named Stellar, who first wrote about these fish some 150 years ago, should have named and described the five species of the genus exactly as they are now known. Since his time no less than thirty-five species have been named by modern writers, their descriptions, correct perhaps as far as they went, being of the same fish in different stages of age, sex, or sexual development. 


\section{The Salmonide of British Columbiat.}

There are five species of Pacific salmon :-

O. chouicha-Quinnet, spring salmon, tyhee.

O. nerke-the sockeye,

$O$. kisutch-cohoe, silver salmon.

o. keta-dog-salmon.

O. gorbuscha-humpback

All these are found in B. C., though all do not frequent the same streams; for instance, there are no sockeyes on the castern shore of Vencouver Island except in the Nimpkish river, and the small streams to the north of it.

There are no humpbacks in the Cowichan, while they abound in the Chemainus river. The tyhee salmon only frequents the larger streams; the cohoe and dogsalmon, every little brook. The time of arrival of the same species, varies in different rivers. Broadly speaking, the tyhee salmon is taken in the late autumn and spring, the sockeye, in the summer, and the cohoe, dogsalmon, and humpback in the autumn.

The tyhee salmon, $O$. chouicha is the largest of the family. Fish of 50 lbs. are by no means rare, and in Rivers' Inlet individuals have been taken over $80 \mathrm{lbs}$. in weight. In the Columbia this species only is used by the best canneries; in B. C. it is more valued as a table fish than for canning purposes, as the color of its flesh cannot always be depended on. I have seen fish red at one end and white at the other, the intermediate part being streaked with red. What causes this difference I cannot say, neither sex nor condition has apparently anything to do with it. There is no external difference between the red and the white meated fish, and many people prefer a white salmon for their own use, believing it to be richer than the colored ones. However, canned salmon must be salmon colored, hence the waste of fish at those canneries remote from the fishmongers. The time of arrival of the species varies slightly in different

and

from

Owi

the 1

table

that

whic

quic

quar

the

to

man

(eve!

for

from

thro the ies. spec not salt 
tyhee.

t frequent res on the Nimpkish

while they only fre1on, every cies, varies salmon is $n$ the sumne autumn. yest of the in Rivers' reight. In canneries; or canning depended the other, Jhat causes ndition has re is no ite meated for their lored ones. hence the shmongers. in different

rivers. At Nanaimo they are taken in the harbor from the middle of November until February, by which time they have left the salt water, and ascended the rivers. In the Nimpkish, I am assured, they arrive in August and spawn the same year. In the larger rivers the early fish proceed upstream to the highest points and spawn in the following autumn. These find their way to the head waters of the Frazer and Columbia, 1200 miles from the sea. Those that ascend later in the spring are supposed to spawn in the lower branches of the rivers.

Unlike the other four species, the chouicha travels singly and is never found in shoals.

O. nerke, the sockeye, is a small unspotted fish, ranging from 4 lbs. in the Nimpkish to 8 lbs. in the Skeena river. Owing to its rich color it is much used by the cannery men, the bulk of the salmon exported being of this species; as a table fish it is dry, and anything but a delicacy. Dr. Bean states that the sockeyes spawn in lakes, and only run up those rivers which flow from such a source. They appear to travel quickly and to great distances inland. I have seen them in quantities at Quesnelle as bright as the day they left the sea, and as red in the flesh. This fish, according to Dr. Jordan, is sometimes land-locked, and I believe the mameet found in many of the rivers and lakes of $B$. C. (even though not land-locked) are of this species. Specimens for identification would be most acceptable, especially from Lac la Hache, or any of the interior waters.

O. kisutch, the cohoe oi silver salmon, may be caught throughout the summer by trolling in Fuca Straits. It ascends the rivers in October, and is used extensively in the canneries. These and the dugsalmon are the most evenly distributed species, being found at the moutl of every little creek. Though not so rich in flavor as the tyhee salmon, it is, when caught in salt water, infinitely superior to the sockeye. 
O. kcta, the dogsalmon, is a fish of 10 or 12 lbs., worthless for either cannery or table use, as it never enters the river until it is ready to spawn. It is however the staple food of the Indians on the coast, who dry large quantities of it, being lean it dries well and does not turn rancid. It must however be noted that neither the dogsalmon, cohoe, or humpback go far inland, so that the Indians of the interior are dependent altogether on those tyhee salmon, or sockeyes, that escape the cannery men.

O. gorbuscha, the humpback is a bright colored fish of from 2 to $5 \mathrm{lbs}$. It never ascends the streams to any great distance, but gencrally runs in large shoa!s a little above the head of tidal water. The female is a shapely little fish, the exaggerated hump and grotesque snout being peculiar to the males. Quantities of these fish are dried by the Indians for food, but they are seldom used by white men either for canning or otherwise.

The first fish to enter the rivers in the spring are the chouicha, or tyhee salmon. These have a long way to go, and a hard road to travel. To say nothing of the dangers from seals and sturgeon, while they are in tidal waters, there are miles upon miles of nets extending around $1 / 3$ of the river from either side, while a third net drifts down the centre. But for the numerous snags and drift timber which in some places impede the nets, one would wonder how any salmon escape, for it must be remembered that they do not travel straight up the river, but run up and down with the tide for some days previously. However we know that a great many do escape, and that they push up the stream through the canon of the fraser, until towards the end of August they arrive at their destination, a different fish altogether from those we saw in tidal wate's, their bodies blotched with red and black, their fins and tails frayed from friction with the rocks, whilc their heads have become long, their noses hooked and their 
worthters the c staple tities of It must phoe, or interior ockeyes,

fish of ny great bove the fish, the ar to the dians for $r$ for can-

are the ay to go, dangers ers, there the river e centre. in some salmon ot travel tide for eat many the canon arrive at ;e we saw ad black, :ks, while and their teeth developed into formidable fangs. Even here they are not free from danger. Weakened by their journey and the buffeting they have encountered in the rapids, they fall an easy prey to the Indian who ruthlessly spears or gaffs them, or corrals them in traps made of split cedar, which extend across the stream. Lampreys fasten on to their sides, and feed on them while living, bears are watching the shallow ripples to intercept their passage, and the bald headed eagle gorges himself until he is almost unable to fly, but sits with drooping wings on the branch of some dead tree overlooking the river awaiting a fresh appetite. But so great is the number of fish, that in spite of all these obstacles thousands survive, and each pair having selected a suitable place for its nest, and forced back any intruders, proceeds to deposit the eggs. For this purpose the male excavates a shallow trench in some gravelly beach where the water is not too swift, and here the eggs are deposited, the female rubbing her sides against the gravel during the operation. The male meanwhile mounts guard, makes furious attacks on enemies, or if these be absent on immaginary ones, returning to the female at short intervals, say of half a minute, to exude his milt on the eggs. The action of the water and of the fish are enough to cover the impregnated eggs or to carry them downstream, until they lodge between some convenient stone, and the object for which the salmon has undergone so much is accomplished.

Such is the proceeding in the upper waters of the Fraser or Columbia river where the fish are comparatively undis. turbed, but in the small streams on the coast, where thousands of dogsalmon and humpbacks are massed together, the scene is very different; here all is activity and turmoil. The males seem to have no time for anything but fighting, and there appears little sign of pairing, in fact it is unaccountable how the progeny or this mass of fish can be anything but hybrids. Perhaps towards the upper or lower end of the pool, a pair 
may be seen sedately at work, but only for a few minutes, a sudden panic secms to take possession of the shoal of fish, they rush up or down stream as the casc may be, completely upsetting the sedate pair, who may perhaps come together again or may find new partners and commence ancw. Here you may sce fish floating downstream with their dorsal fins out of water, rolling over when they come to a shallow ripple, without strength enough to kecp their heads upstream, others at their last gasp, decomposed even before death, floundering on the edges of the stream, while the trout are busy stealing the cggs as fast as they are laid. Lower downstream a flock of ducks is devouring the spawn, or perhaps wallowing in the dead salmon. The more putrid it is, the more it secms to be appreciated. An oily scum floats on the water, which is so impregnated with particles of the rotting fish that it is a wonder how anything can exist in it for even a minute, and yet I have every reason to belicve that some individuals do survive and even recuperate in the fresh water before return. ing to the sca. I have taken spent salmon in the North Thompson that were strong enough to make a good fight, and I could see nothing to prevent these from returning. At one time it was supposed that no salmon ever did so, but of late this opinion seems to be much modified, c.specially with regard to the tyhee salmon. Unlike all the other species, which are almost always an uniform size, these fish are found in the rivers ranging from 2 to 70 lbs. with milt fully developed. How is this? They cannot very well be of the same age, either the $70 \mathrm{lb}$. fish has returned from one or more trips in the river, or he has remained in the sea for some years, although we see that he was perfectly able to breed when he was two pounds in weight.

Dr. Jordan states that at the hatchery on Rogue River the fish are stripped, marked, and set free, and every ycar since the hatching has been in operation, some of the marked

fish

fishe thou or 0 recei ente have this the of $b$ three large food have pose that the caug geno if it do $\mathrm{s}$ I ha grils milc I5 ston fres: fem dev as $\mathrm{i}$ star hoo larl at it 
hutes, a of fish, nplctely together Here rsal fins $v$ ripple, h, others undering stealing a flock ing in the $\mathrm{ms}$ to be ch is so $t$ it is a utc, and duals do e return1e North fight, and At one $t$ of late lly with species, re found ly develthe same lore trips ac years, when be

ue River ery year marked fish have been recaptured. Mr. Mowat, our Inspector of fisheries, also reports the same of the sockeye salmon. Although we know that some species of salmon will take a fly or other bait in the rivers and lakes, it is a gencrally received opinion that they cease to fecd when they enter fresh water, and exist entirely on the fat they have accumulared during their stay in the sca. Possibly this theory may arise from the fact that on entering the fresh water the stomach of a salmon contracts, and instead of being a membranous sac capable of containing two or three herrings, its walls are thickened and it becomes no larger than the stem of a tabacco pipe. It is certain that food is scldom found in their stomach, and many theories have been advanced to account for this. Some have supposed that the digestive powers of a salmon are so strong that the food is absorbed at once, while others maintain that the contents of the stomach are ejected when a fish is caught. Against the latter theory is the fact that food is generally found in a salmon taken by trolling in the sea; if it unvariably ejects food in fresh water, why does it not do so in salt? That some of our salmon feed in the rivers I have not the least doubt. Last spring (April) I took a grilse $(O$. chonicha) of $6 \mathrm{lbs}$. in the Cowichan river about 14 miles from the sea, that had, as nearly as I could ascertain, I5 small salmon fry, in all stages of digestion, in its stomach. Now this fish must have taken the fry in fresh water, because there are none in the sea. It was a female, in splendid condition; the ova were but slightly developed, and 1 ioticed there was not as much internal fat as is usual in a fresh run fish. Perhaps but for one circumstance this fish might have ejected its food. It was hooked at the head of a bad rapid which I was particu. larly anxious to avoid running. Of course, I could not at first tell the size of my fish, but I detcrmined to give it all the strain I could to prevent it going down stream, 
and this I did until it was landed. The consequence was the fish always had its head upstream in a rapid current, and could not possibly vornit, even were it desirous of doing so.

I am of opinion that much depends on the sexual condition of the fish. If the eggs be fully developed I do not think they feed, but should the ova (or milt) be immature, or the fish have already spawned, I believe they may be taken with fly or by trolling as well here as elsewhere. We know that the spring salmon, $O$. chouicha, enters the river in the winter, and does not spawn until the following autumn; its eggs therefore must be immature, and if $m y$ theory be correct, they should feed in the rivers in spring, and in the lakes during the summer.

Very little is known about salmon fishing (angling) in British Columbia. I believe the Cowichan river is the only one that has been tried in March or April, and it has invariably been with success. Later in the season, say June or July, the fish have left the river on account of low water, and have reached the lake at its head; at that time, I am informed, they are constantly taken by trolling. A good deal of light might be thrown on the subject by examining each fish caught and noting first the species, and date of capture; 2 nd the contents of the stomach; 3 rd the development of the eggs or milt, or whether spent; and $4^{\text {th }}$ the amount of internal fat.

These remarks apply only to the spring salmon $(O$. chou$i c h a$ ), but with reference to the summer salmon, O. nerka, the sockeye, I am informed that two gentlemen took about 40 of them last summer at the outlet of the Cowichan Lake. They were all taken with fly, and averaged about 4 lbs., the two largest being $8 \mathrm{lbs}$. each. As these fish have only recently been introduced into the Cowichan, very little is known about their sporting qualities, and I should be glad of detailed well authenticated notes.

the 
O. kisutch, the cohoe, an autumn fish, will take a fly freely in the tidal waters when it first enters the rivers. I once caught five in about two hours at the mouth of the Nanaimo river. In all probability my theory will be found correct here, for I must have cast over 500 fish for every one I rose, and all I took were fresh run and clean fish, that had not been in tidal water long, therefore the eggs could not have been very well developed.

As far as I am aware there are but two species of trout in British Columbia, viz: Salmo purpuratus, the red throated trout, and Salmo gairdm(r)ii, the steel head, or "Sow cum" of the Cowichan Indians.

The former is the common trout of the country, found in almost every stream and lake from Oregon to Alaska, and from Utah to the Pacific.

In all species having such a wide geographical distribution, there is naturally a tendency to variation in form, size, or color, in different localities. Other changes are caused by difference of age, feed, condition, temperature of watcr, the nature of the bottoms of streams or lakes, the size of the bodies of water, the different stages of sexual develop. ment or by a tempory residence in the sea. Specimens taken in a lake on the same day will vary from one or another of the above causes; some will be dark colored and thickly spotted, others silvery and almost immaculate. In some the scales will appear larger than in others; some will be short and deep with small heads, others long, lean and lantern jawed. In the rivers it is the same; those taken in the rapids will be bright colored, those in the backwaters will be foul fish, while those fresh run from the sea will be bright colored and apparently unspotted.

Sizc is dependent principally on the quality and quan- 
tity of fecu, and the larger the lake or river, the larger as a rule the fish will be. Mr. Baillic Grohman's land locked salmon (which is merely an overgrown trout) attains a weight of 20 lbs, in Kootenay Lake.

Those that have access to the sea, are generally larger than those taken from lakes; there are exceptions to this in some few lowland lakes, where fish being few and food plentiful, you will find them of 3 or $4 \mathrm{lbs}$.

Some breeds (not species) of trout are larger than others; in the higher mountain streams, fully developed trout $2 \frac{1}{2}$ inches in length may be found, with the parr marks still on them, half starved little fellows who hardly ever see a fly in their lives, unless it be the ubiquitous mosquito.

Few trout appear to stay in the streams during the winter, preferring to run down to the sea, or to ascend to some lake where the temperature of the water is milder, and food more plentiful.

The spawning scason of these fish is from November to April according to locality. In the small mountain streams they appear to spawn later than in the lakes, and it is not unusual to take an occasional trout with eggs fully ripe at any time of year.

S. purpuratus may be distinguished from S. gairdnerii by the smaller scales, the red patches on the outer edges of the lower jaw, and by the caudal fin which is slightly forked, whereas in the latter it is truncate. The wrist of the tail is much more slender than that of S. gairdnerii. Both species are black spotted.

Salmo gairdnerii is a large anadromous trout that ascends the rivers in the early spring, spawns about the beginning of April, and after recuperating in the rivers, and

doin the

the

lbs., salm

The

solic

ycllc goes I do thou whic In $\mathrm{t}$ so th cend are : foun trea Babi Who river arriv fly salm brut

be nati Jorc sain spec

the lake 
doing all the mischief he can with the salmon fry returns to the sea about the end of August. When fresh run from the sea it is a handsome fish attaining a weight of 25 lbs., but becomes discolored when spawning; like the salmon many die from exhaustion during this operation. The bones of this species are much coarser and more solid than any of the other salmonidæ, the flesh is a pale yellow. Very little is known of the time when this fish first goes to the sea, as the young in the smolt stage are seldom taken. I do not think I have ever seen more than half a dozen, though they are easily recognized by the size of their scales, which are fully half as large again as those of $S$. purpuratus In the parr stage they would not be so easy to indentify, so that in all probability they assume the smolt dress and descend to the sea during the late autumn when no fly-fishermen are at work. This species has a large distribution being found from California to Kamschatka in almost all the larger treams. I am informed it is also taken in the spring in Babine Lake, where they run as large as 30 lbs. Whether this fish will take a bait or fly on entering the rivers I do not know, as it is the close season when they arrive. As mended kelts they are very voracious and take fly or minnow freely; it has not, however, the dash of a salmon, but plays sluggishly, and it is merely a matter of brute strength to bring it to land.

airdnerii edges of y forked, he tail is th species

out that ibout the vers, and

Although I have never found it in B. C., I should not be surprised to hear that the rainbow trout, $S$. irideus, is a native of the streams flowing into the Columbia river. Dr. Jordan has doubts whether this species is not a breed of $S$ gairdnerii debarred from access to the sea, as he can find no specific difference between the two.

The two charr indigenous to B. C. are Salvelinus malma the Doily Varden trout, and Salielimus namaycush the great. lake or Mackinaw trout. 
The first named is distributed almost as widely as the common trout; it is found from California to Kamschatka, and extends even across the Rocky mountains. I have taken it in the Athabasca, which flows into the Arctic Ocean, and also in the Saskatchewan, one of the higher tributarics of the Hudson Bay. It is singular that it is so seldom found on Vancouver Island, the only rivers that I know it frequents being those on the eastern shore north of Comox. Near Masset on Queen Charlotte Island it is very plentiful, and there I caught it in the seapools in conjunction with $S$. pur. purutus taking sometimes one of each on the same cast. It is common in almost all the waters of British Columbia, and appears to be wonderfully able to adapt itsclf to circumstances, whether in the sea, the lakes, the rivers, or the milky glacial streams. I have never taken one over five pounds in weight, but it is probable they attain a much larger size in the large lakes of the mainland. This is the most gaudy of our salmonide, the back is olive green, with spots of a lighter shade; below the median line, it is golden with pale salmon colored spots; the lower fins are grey edged with a narrow band of yellow. It can hardly be considered a game fish, as it usually prefers a piece of bacon to a fly; it is however, when camping, an acceptable addition to the pot, many persons considering it superior to the trout.

Of the grayling, Thy'mallus signifer, I can tell you but little, as I have never taken it in British Columbia. It appears to be common in the Cassiar country, and is known there as the Arctic trout. Two specimens sent me by Mr. James Porter from Dease Lake were too delapidated to be of much use; I noticed however, that the dorsal fin resembled that of the variety tricolor more than signifer. The local name of grayling is applied to some of the upcountry Coregoni, specimens of which are badly wanted in the Provincial Museum for identification. 
Stenodus Mackenzii the Inconmu, a large fish intermedi-

as the hatka, taken $\mathrm{n}$, and aries of und on quents Near $\mathrm{ul}$, and S. purist. It ia, and umstanmilky unds in ze in the of our lighter salmon narrow me fish, however, any peryou but bia. It s known e by $\mathrm{Mr}$. ed to be esembled The local ipcountry le Provinate between the salmon and whitefish, is said to be found in Stuarts river. Dr. Dawson found it in the upper tributaries of the Yukon, and in all probability it is common in the northern parts of the province.

Little is known of the range of the whitefish (Coregoni) in British Columbia. One species is found in Lac la Hache, and another, that I believe to be $C$. Williamsoni, is known as the Round fish, and is common in many of the upcountry streams and rivers.

In conclusion I would say that this paper is written not so much to impart information as to shew how little we really know about the most valuable fishes of our Province, and also in the hopes that some of our upcountry members will be in. terested enough to collect notes on the habits of the fish in their several localities, and forward them to the Provincial Museum.

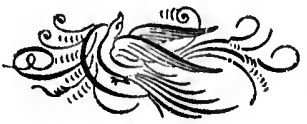




\section{THE ECOMONIC FISHES}

\section{- OF- \\ British Columbia.

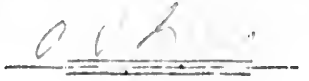

able

figu

thro

used

the winter supplies of thousands of Indians. Unlike the Indians of the plains whose lives depended on their exertions, and who had to roam over a vast extent of country to obtain meat enough to put up for winter use, the fish eating Indians could count securely upon their winter supplies coming to their very doors.

But all this has changed within the last few years; except in remote districts salmon is no longer the staple food of the Indians; flour, tea, tobacco and clothes, formerly luxuries to them, are now necessaries. To obtain these they must work, and what employment could be more congenial to them than salmon fishing; hence it will be found that most of the salmon canned in B. C. are taken by Indians.

Twenty years ago there was not a salmon cannery in the country, and few people could have foretold the rapid growth of this industry. To-day there are 34 canneries, and B. C. salmon can be bought in almost every country on the globe. 
Through the kindness of Mr. Trotter Johnston, I am able to give the total pack for the past fifteen years:

CASES.

CASES

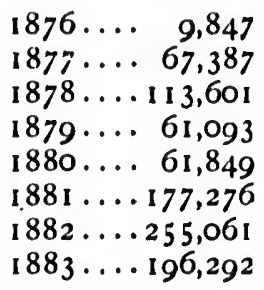

I $884 \ldots 141,242$

$1885 \ldots 108,517$

I $886 \ldots$. I6I,264

I $887 \ldots 204,083$

I $888 \ldots$. . I 84,040

I $889 \ldots .414,294$

I $890 \ldots 409,464$

$y$ record nong the ach year into the rvest, the e Indians ;, and who ain meat lans could to their

zw years; taple food ierly lux. hese they congenial that most

ery in the id growth and $B$. C. he globe.

Assuming $\$ 5$ to be the average value of a case, these figures shew that over $\$ 2,000,000$ were last year circulated through the province by this industry alone, every article used in which, with the exception of the tin for cans, being the produce of the country.

I am unable to give the number of people directly em. ployed in this business, but they are principally Indian fish. ermen, and Chinese packers. Indirectly employment is given to boat builders, net makers, saw mill hands, shippers, freight handlers, store keepers and farmers; in fact there are few people residing on the coast who do not benefit in some way by the salmon canning traide.

Of the five species of salmon frequenting our water three only are used for canning. These are the sockeyes, (Oncorhyuchus uerke) the spring salmon, $(O$. chouicha) and the cohoe, $(O$. kitsuch). The first having the richest color, is most in demand, the second is the best in flavor, but owing to want of color in many of the fish, it does ilot seem to bc a favorite with the cannery men. The third coming late in the fall, is used to make up the pack of each cannery, should the run of sockeyes prove a bad ons. 
The Economic Fishes of British Columbia.

I believe that owing to the unprecedented run of sockeyes in the Frazer, no cohoes were used last season.

The sockeyes make their appearance in the rivers about the first week in July; the cohoes about the middle of September. The spring salmon is plentiful on the coast from November to April, but does not run up the rivers in dense shoals like the other two species.

In addition to those consumed in the cannery business, great numbers are salted or frozen for export, while there is always a demand in the local markets for kippered salmon. As for fresh fish they can be found on the fish stalls almost every day in the year, and the consumption must be very great, though of course there are no means of obtaining any data as to the quantity consumed. Although not used to the same extent as formerly, thousands upon thousands of fish are still dried by the Indians. When thus prepared, the salmon is both light to carry and very nutritious. An Indian going on a journey will wrap a few fish in his blanket and be provisioned for a week.

In spite of the enormous quantity of salmon consumed and destroyed each year, their numbers in this Province do not seem to have diminished. This, no doubt, is owing to wise legislation which forbids all net fishing above tidal water. In the Columbia river it is different; there fishing is, or was, permitted everywhere. Travelling by the N. P. Railroad, some of you may have noticed water wheels placed on the points most frequented by salmon. The floats (if they may be so called) are scoop nets which catch any passing fish and lift it into a trough down which it slides into a receptacle placed to receive it. These wheels are very destructive.

In $187 \mathrm{I}$, when at the head waters of the Columbia, I saw thousands of large salmon (chouicha) at the outlet of

Coluı pair, they river runs may wates

point large spike The in $\mathrm{frc}$ spike

in $\mathrm{B}$ from sepa stear is ob carti as it is a quar ville coas Ind likc fish 
Columbia Lake. In 1887 , at the same place, I saw but one pair, and the Indians informed me that the previous year they had only taken five fish. Whether the injury to the river is permanent or not remains to be seen; the salmon runs vary so much each year that possibly these two years may have been bad ones, and but few fish reached the higher waters.

Next in importance to the salmon, from an economic point of view, is the dogfish, of which two species exist in large numbers on our coast, viz.: Squalus acanthias, the spiked dogfish, and Galeorhinus galeus, the tope shark. The former may be easily distinguished by the long spike in front of each dorsal fin, the latter by the absence of the spikes, and the notch on the upper lobe of the caudal fin.

At Skidegate, on Queen Charlotte Island, and at Ecole, in Barclay Sound, are large factories for the reduction of il from these fish. The livers are first taken out and rendered separately, thus obtaining a pure oil. The bodies are steamed in large retorts, and from them a much inferior oil is obtained, containing a large amount of gelatine from the cartilage of the fish. Tlis makes the oil unfit for marhinery, as it gums, but it is useful for a number of other purposes. It is almost wholly consumed within the province. Large quantities of dogfish oil are also made by the Indians; some villages producing as much as 9000 gallons. On the West coast, during the autumn, I found it difficult to engage Indians even at $\$ 40$ a month and board, as they could, if they liked, make double that it dogfishing.

In addition to the dogfish there are several oil bearing fish in our waters, which may at some time be utilized. Chimara colliai, the rabbit fish, is sometimes very abundant, as many as 300 having been taken at one haul of a net in Esquimalt harbor. The crest of the male is a source of much 
annoyance to the fishermen on account of its becoming entangled in the nets. The oil procured from the liver is said to be very fine and is used for watches, gun locks, sewing machines or any other small machinery.

Cetorhinus maximus, the basking shark, is, I am informed by Indians and whalers, plentiful in Queen Charlotte Sound during the summer months. This shark attains a length of 30 feet or more; it is perfectly harmless and so tarne while basking that it may be touched with the hand. Like the whale it is taken with the harpoon, but its capture is more difficult and dangerous, for the reason that when struck it dives to the bottom and cannot be brought to the surface to be killed. Sometimes a boat may be attached to one for 24 hours before it is exhausted; in the meantime, wind or fog may arise, or the position of the vessel lost, in which case the boat's crew is exposed to great risks. Perhaps the bomb lance used on this coast a few years ago for whales might be used with advantage on this fish. I have only hear : of them being killed occasionally by Indians on our coast. In England, 150 gallons of oil is the average yield of the liver, which alone is rendered.

Halibut (Hippoglosses vulguris) are most abundant on the west coast of Vancouver Island, though occasional fish are takeia on the eastern ahore. They appear to vary greatly in quality and size, according to the locality, they are found in. Those brought to Victnria are very inferior when compared with specimens from the northern end of the Island, and the same remark applies to the sea bass, skill, and many other fish.

Halibut are to the westcoast Indian what the salmon are to those residing on the east coast or mainland. The rivers on the west coast are generally small, and afford comparatively few salmon. Some tribes have only one or two brooks in 
hing en$r$ is said sewing

I am en Charattains and so he hand. capture is en struck e surface one for nd or fog hich case the bomb might be $\therefore$ of them In Engver, which

Indant on ional fish ry greatly are found hen comhe Island, and many

almon are The rivers omparativbrooks in

which they have the right to fish, and must depend to a large extent on the halibut fishery. Starting at night, these hardy fishermen put to sca, so as to be on the fishing ground (per. haps out of sight of land) by daybreak. A very few hours suffice to take all they want, (for an average fish will weigh jo or $60 \mathrm{lbs}$.) and they are generally home again by noon. Rough weather may interfere with their success, but generally they will have 3 or 4 fish, and I have seen canoes with 15 or I 6 fish in them, which the men were glad to sell at 50 cents apiece. The hand lines used are made of lengths of kelp knot. ted together, and the Indian halibut hook is invariably used. Although this appears to be a clumsy contrivance, it is deadly, a fish once taking the bait being hooked to a certainty. Even the white fishermen prefer them when halibut fishing. When brought to the surface the halibut is knocked on the head, and if large the canoe is tilted until the gunwale is level with the water when it is dragged on board.

Fish that cannot be utilized while fresh, are cut into thin flakes and dried in the sun. These look well and would, I believe, find a ready market but, for the certainty that the greatest disregard for cleanliness has been observed in their preparation. Were they cured and put up neatly by white labor I have not the least doubt they would sell well.

Although not much utilized on this coast, the sturgeon is of considerable commercial importance in some countries. The roe, when salted, forms caviare, ${ }^{*}$ and the bladders are manufactured into isinglass. In the eastern states they are sometimes dried and smoked, and are said to be palatable when thus prepared.

Our sturgeon (Acipencer tronsmontanus) enters the Frazer about the end of April at the time of the oolachan

* Caviare is not necessarily stilted. Fresh caviare, $i$. $e$, the silsple roe of the sturgeon, commands the highest prices and is almost the only caviare eaten in Russia. C. P. W. 
run. In all probability it spawns very shortly afterwards, as the ova are fully developed in May. I have never been able to asc :rtain where or how they spawn, though I have been informed by the Indians that the lakes and deep holes in the rivers are much frequented by them about that period.

They are taken by spearing or by night lines baited with a piece of salmon; great numbers are also taken in the salmon nets.

The largest sturgeon I have seen was said to have weighed 700 lbs. Occasionaly fish are taken in the smaller rivers; this autumn I saw two of about 150 lbs. each, that had been taken in the San Juan, on the west coast. The Indians told me they were constantly taken in a deep pool at the mouth of the river, but that they never went up stream.

In the Kootenay Lake and river, sturgeon are also found, but whether they are of the same species as those on the coast I cannot say, as I have never had the opportunity of examining one. No doubt they are found in other lakes in the Province, and I should be glad to receive any information on this subject.

Of the Scorpœnidæ, several species are found on the fishstalls. Sebastichthys rubra, and S. pinniger, both called red bass, and S. melanops, the black bass, are the largest and therefore the most important. As food fish they are unsurpassed by any in our waters, though rather expensive fish to buy, considering the amount of head and offal you have to pay for. The red bass are essentially deep sea fish, and particularly liable to have their stomachs expelled from their mouths by the sudden expansion of their air bladders on being brought to the surface. They are oiten found dead from this cause in the neighborhood of rapids. All these fish are ozoviparous; though I have examined many a bulky

speci

the $y$

the $f$

one

the

gene

other

to br

head

weed

shape

relea:

to th

borhe

weigl

mus,

dem

ed fo

some

small

of ke

our n

wate are west recen them the 
wards, as been able ave been oles in the d.

les baited en in the

to have 1e smaller each, that ast. The ep pool at stream.

also found, ose on the rtunity of $r$ lakes in fformation

id on the oth called argest and are unsurive fish to $\mathrm{u}$ have to , and parfrom their ladders on ound dead 1 these fish a bulky specimen, I have never myself been fortunate enough to find the young within the fish.

Ophiodon elongatus, or the cultus cod as it is called by the fishermen, deserves more than a passing notice, since it is one of the best food fish we have, and in season almost all the year round. It is common everywhere on our coast, generally hiding in eel grass or kelp. It takes spoon or other bait freely, but when angling for it care must be taken to bring the fish to the surface quickly; if it once gets its head down, nothing will prevent it from running into the weeds, when of course it is a case of good bye spoon at least.

The Indians take this fish by sinking a wooden bait, shaped like a shuttle cock, at the end of their spear, and releasing it at the bottom. The fish follows the shuttlecock to the surface and is speared by the Indians. In this neighborhood it spawns about the end of February, and ranges in weight from 2 to $40 \mathrm{lbs}$.

Another of the same family is (Hexagrammus aecagram. mus,) the kelp trout of our markets. There must be a large demand for this fish if one may judge by the quantity expos. ed for sale; for my own part I consider it worthless. It is sometimes dried and smoked. It feeds on shrimps and other small crustacea, and is caught by nets placed within the beds of kelp. It spawns about the middle of October.

Anoplopoma fimbria, the skil, is not often found in our market, the adults keeping far out in the Straits in deep) water; the young however are often taken at Esquimalt, and are known as mackerel. These fish are abundant on the west coast of Queen Charlotte Island, where there were, until recently, several stations established for the purpose of curing them. The mode generally adopted was that of pickling, the fish being too fat to dry-salt, and turning rancid 
when kept a short time. I am sorry to learn that as a com. mercial venture this fishery has been abandoned, the labor and expense involved being disproportionate to the returns when compared with other fisheries. Opinion varies regarding the qualities of this fish on the table. Those brought to Victoria are dry, and very inferior. I have never had an opportunity of tasting one from Queen Charlotte Island, but I can very well believe that there they are excellent. As I remarked before, there is no comparison between fish of all kinds in Queen Charlotte Sound, and those taken near Victoria.

Of the Gudidce we have several species, though most of them are rare about Victoria. The common cod, Gadus macroccphalus, appears in several of our harbors and inlets, about January, for the purpose of spawning, but they are small and not in sufficient quantities to supply more than the local demand. I have never seen one over $8 \mathrm{lbs}$, and fully onethird of that weight was the roe. In Behring Sea they attain a much larger size, and are caught in greater numbers. Fish of $30 \mathrm{lbs}$. are there by no ineans rare.

G. proximus, G. chalcogrammus, the whiting, or tom cod are not uncommon, and the Hake, Merlucius productus, though seldom seen in our markets, is common nothward.

In the up country lakes and rivers a fresh water cod, Lota maculosa, is extremely plentiful. It is, I belicve, identical with the Turbot of Europe.

Several species of flounders or dabs are found on our coast, the most common of which is the starry flounder, Pleuronectcs stellatus. You will easily recognize this fish by its rough tubercles or scales, and by the verticle black bands on its dorsal and anal fins. Dr. Jordan states that it reaches a weight of 15 to $20 \mathrm{lbs}$. ; I have never seen a specimen over 6 or $7 \mathrm{lbs}$. This flounder is peculiar in that it is not, as is 
com.

labor

returns arding; to Vicoppor. t I can narked inds in

h most Gudus inlets, e small e local ly one$y$ attain

Fish

or tom ductus, thward.

er cod, believe,

on our oinder, fish by bands reaches ien over t, as is

usual in most flat fish, constantly colored on the same side. The halibut swims with its right side uppermost, the turbot with its left side, but as many right hand as left hand starry flounders are taken.

I need not tell you that we have no soles in the Pacific, the plaice, usually so called by our fishermen being the Plcuronectes zetulus. It is a small fish seldom weighing more than a pound, but what it lacks in size it makes up in quality. It may be known by its peculiar pointed head.

These two, together with the halibut, form the bulk of flatfish seen at the fishmongers, but specimens of Plcuroncetcs bilincatus, Pleuronicthys canosus, Psettichthys melanostictus, and Citharichthys sordius are also common. There are also occasional specimens of many other species, but they are so seldom seen that they cannot be said to have any economic value.

Of small fish, or as our Arnerican cousins call them, panfish, we find several kinds on our fish stalls.

The herring (Clutea mirabilis) arrives in the early spring for the purpose of spawning. Although equal to the English herrings in flavor, they are far inferior in size nevertheless large numbers are consumed both fresh and in the form of bloaters. Indirectly these little fish do us a service, since larger and better fish come inshore to feed on them. Many herring are salted down in bulk as bait for the dogfish and other fisheries, and some time ago there was a factory at Burrard Inlet for the extraction of oil and fish guano from them, and from salmon offal. Unfortunately however this was burnt down and has not been rebuilt.

Herring spawn is an article of barter among the Indian $_{\mathbf{S}}$ who consider it a delicacy. It is found attached to the 
broad leaves of the kelp in such profusion that the kelp is entircly hidden. In this state it is eaten leaves and all; for trade it is scraped from the leaves, and stored in square cedar boxes.

The oolachan (Thaleichthys pacificus), an anadromous fish of about 9 inches in length, makes its appearance in the tidal waters of the Frazer about the middle of April, and in the Nass about the 23 rd of March. When fresh is a delicious little fish, but it deteriorates with carriage, and is never seen to perfection in the Victoria market. Numbers of oolachans are put up in pickle in small kits, and some are cured and smoked like bloaters.

Oolachan greasc is an article much used and appreciated by the Indians. A large trade is done in this commodity between the Indians of the Nass river and those of the interior, in exchange for furs. In appearance and consistency it resembles lard. and is used on diried salmon or halibut, much in the same manner as we use butter on bread. A short account of its manufacture on the northern rivers may be of interest to you. As I before stated the oolachans arrive in March when the ice is still on the river. All the Indians who have any right to fish in the river, and this priviledge i; jealously guarded, come from far and near to the fishery, and erect temporary dwellings along the banks or on the ice. The fire wood for trying out the oil has to be brought from a distance, all that in the immediate vicinity of the fishery having been used long agro. The fish are taken under the ice with purse nets, and are left in heaps until they are, to say the least of it, high; partial decomposition assisting the extraction of the oil. They are then boiled in troughs which are about 5 feet long by 2 feet wide, and the fat is skimmed off, and put into square cedar boxes about the size and shape of a coal oil tin. Originally the grease wi extracted by filling a wooden trough with water, and heating it with red 
hot stones, this mode is now obsolete, the troughs having at shect iron bottom built over a long and narrow furnace.

The oolachan has more than its fair share of enemies; sturgeon, salmon and porpoises follow it into the rivers, while bears and the settiers' pigs gorge themselves with the exhausted shotten fish. At Port Hammond I once saw two pigs standing up to their backs in the water, and diving for oolachans; they seldom failed to bring one up.

Two smelts, Osmerus thalcichthys, and IIyomesus pretiosus, are tolerably plentiful in our market, and are generally confounded with the Atherine (Atherinopsis califormicusis) which they somewhat resemble. The latter however may be recognized by its want of the adipose dorsal fin.

The Anchovy (Stolcphorus ringens) is at time, very plentiful, though months may clapse without its being seen on the fish slabs.

The Capelin (Mallotus zillosus) was first observed by me two years ago, when I saw about a bucketful in a Johnson strect fish store. Last year they were plentiful for about a week in July. Although common in Alaskan waters, they appear to be only occasional visitors to our coast.

The most abundant skate on our shores is Reria Cooferii. As food it does not appear to be held in much estimation, probably on account of its repulsive appearance, and that until lately the fishmongers did not take the trouble to crimp it. It grows to a large size, and according to Dr. Jordan is sometimes taken over 6 feet in length. The empty handbarrow shaped egg cases are often found on the seashore, though it is seldom they are obtained with the young fish in them. One opened by me at the Provincial Muscum, con. 
tained three perfectly developed youngsters with the umbilical sac still attached; this is the only instance in which I have known more than one fish to be produced from an egg.

A second species, R. rhinc, is occasionally found in the markets. It does not attain the size of $R$. couperii, from which it may be distinguished by its long tapering snout.

Although the bait question has not assumed the importance that it has in the older provinces, $t^{2}$ : day must come when its value will be appeciated; this paper therefore would not be complete, were the subject wholly ignored.

The favoritc bait with our fishermen is the octopus, common enough on our shores, but difficult to collect in sufficient quantities to fill the demand. Herrings at times may be taken by the ton, and when salted are the cheapest bait that can be procured; in fact there is little clse to be obtained in the winter. During the summer there is little difficulty in procuring all that is wanted, smelt, atherine, anchovy and the different species of Ditrema can then be taken in numbers. The Sand launce, Ammodytes personatus, is very plentiful, and if a dainty bait, and one highly prized by the Dutch fishermen, be wished for, there is the river lamprey (Lampetra tridenat $(t)$. These little fish ascend the rivers in thousands, and I do not know of a more curious sight than is to be seen in any of the canons of our larger streams during thcir migration upwards. Some few attach themselves to the sides of salmon and save themselves an immensity of trouble by doing so, having their passage free and meals also, but the bulk of them toil upwards, resting sometimes in the swifter parts of the river by holding on to a stone. Should the water become too rapid to stem by swimming, the lamprey holds on to the rocks at about the water line, and, during the momentary periods when it is left dry, manages to advance an inch or so by a succession of jumps, holding on whenever the water rises,

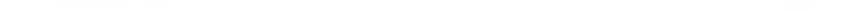


umbilih 1 have $g$.

$d$ in the ii, from out.

impor-

ist come c would

octopus, $t$ in suffi. may be bait that ed in the n procurand the numbers. plentiful, utch fish. ampetra lousands, be seen heir migsides of by doing bulk of parts of $\mathrm{r}$ become on to the omentary hor so by iter rises, and there is danger from the current. At the Scutz canon in the Cowichan River, where the whole stream is confined to a cleft in the rock only about 9 fect in width, I have seen the lamprcys hanging to the perpendicular rocks so thickly, that a landing net would take a dozen or more at a time. No difficulty seems to be experienced as long as the walls of the canon are continuous, but should there be a turn to make the lamprey generally comes to grief and is swept down by the current to try again.

Whelks, cockles, clams and crabs are to be had in large quantites, both in the winter and summer months, and are largely used by the Indian fishermen, who prefer the clam as a bait when trolling for salmon.

From the foregoing pages it will be seen there is no scarcity of good fish on our shores, and yet for some cause less is used in Victoria than in any seaside town I know of. The reason is not hard to find. In the first place, fish is much dearer than butchers' meat. Even the inferior kinds caught in our harbor, such as the Chirida, and flounders, sell for 15 cts. a pound, offal included. The fishing boats used are small, and have no room for ice, nor do the fishermen appear to think it necessary to use it, consequently the better kinds are stale before they are landed, their condition being exceeded only by the price asked for them, both are so high. Again the supply fluctuates; one day the market is glutted, and for several days afterwards there are none. I am afraid want of competition is the cause of this; the fishermen are few and perhaps too well off, and consequently have not to go out every day. Last week I heard of a man who took a ton of halibut in one night (no unlikely catch), brought them into Victoria and sold them at $5 \mathrm{cts}$. a pound, making $\$ 100$ for his day's work; no doubt this was an exceptional case, but a fisherman who can do this need not go out in bad weather, and provided he has facilities for cold storage, could keep the town supplied with regularity, and at a reduced price, with but little hard work, and no risk to himself or boat. 


\title{
$\checkmark$ NOTES
}

fied

deed

it is

slatc

DPON THK

\section{Manufacture of Jade Implements}

\author{
IN BRITISH COLUMBIA
}

AND THEIR GFHNOLOGICAL SIGNIFICANCE.

silks

whic

cape

very

T was unaware when I proposed dealing with this subject, of an interesting paper contributed by Dr. Dawson some three years ago to the Canadian Record of Scicnce upon "The Cicurrence of Jade in British Columbia."

I am afraid the existence of this paper will deprive the few remarks I am able to make of any claim to originality, Dr. Dawson having already explained the method adopted by the natives in manufacturing their implements, which so far as I am aware has not hitherto been correctly described, though Sir John Lubbock in "Prehistoric Man" has evidently alluded to the same process when describing the making of stone axes. (p.p. 96, 97.)

Jade, Nephrite and Jadeite are minerals which possess similar properties, and have been used indirferently for the same purpose. The two former are Magnesium or Calcium Silicates, the latter is an Aluminium Sodium: Silicate. Their usual appearance is well known, it is that of a somewhat attractive stone of varied color, white, green, brown to almost black, with sometimes streaks of yellow and red. When pure it is probably like a form of the Chinese jade, milky white, and the other colors are due to the presence of foreign matter. So too it should be translucent, but is found almost opaque from the admixture of less vitri-

poir in $\mathrm{t}]$ best to it of :

$\min$ ams of $t$ par on $\mathrm{Sib}$ Bri hav cou mir me sto: con

- $\mathrm{Ne}$ ver. 
ficd minerals. The commonest prevailing color is green, indeed to everyone who is unfamiliar with the Chinese variety, it is known as a green stone, and implements of greenish trap slate, or serpentine are frequently said to be of jade.

It is by no means of common occurrence, and would seem to have been more generally discovered in the form of stream boulders and pebbles than in its matrix.

To the touch it is agreeably smooth and somewhat silky, pieces struck together clank with a certain resonance which is said to be much admired by the Chinese, and it is capable of being ground to a cutting cdge, which though not very sharp retains an excellent temper. Indeed it has been pointed out, its value consists not so much in its hardness as in this property of temper, in whicin it may be said to be the best stone substitute for steel. This quality is probably due to its fibrous structure, which can often be seen in the fracture of a piece of the rock.

But the peculiar interest of this otherwise obscure mineral, is due to the high esteem in which it has been held among prehistoric and savage races in widely separated parts of the world. Among the lake dwellings of Switzerland, in parts of Germany, in Southern Italy, in Brittany, in Crete, on the earliest or nearly the earliest site of Ancient Troy, in Siberia, China, India, New Zealand, the Pacific Islands, British Columbia, Mexico, Central America and Peru, men have left testimony of their recognition and esteem for jade.

Now, if it had been of fairly common occurrence in these countries, there would have been nothing wonderful in a mineral the economic properties of which were evident, commending itself to the notice of those who depended upon stones for all their tools. But nowhere can jade be called a common substance. Even in those countries as China and - New Zealand, where there is any degree of abundance, it is very local in its occurrence, while in by far the greater num- 
bar of the places where articles of its manufacture have been discovered, no native mineral is now known to exist.

the

Par

Again, it has been pointed out that except in China, there is no evidence of a continuous recognition of its value from prehistoric times. The Greek, the Roman and the Teuton hardly knew of such a substance except from the few specimens they might find and treasure as curiosities, like ourselves. The Egyptian and Assyrian seem to have set as little store by it. The Hindoos re-discovered its value in the time of the Moguls. The Spaniard learnt to prize it from the Mexicans, and called it "piedra de ijada," or groin stone, because of its supposed efficacy in disease of the kidneys. (of Nephrite, Kidneystone, fr. nephroi, Gk., Kidneys.)

No ancient language, except Chinese, as far as we know, has a name for it, no modern tongue calls it by any word that is not merely epithetical. It would seem to have dropped out of notice at some very early period, only to be re-discovered in a manufactured form, and reverenced as the relic of a long forgotten or perhaps divine race.

It will be readily seen what a fascinating problem all this presents to archieolcgists, what a delightful opportunity for speculation; and it is one they have not failed to seize upon.

It has been supposed that one source, an Asiatic one, has provided the jade iinplement: discovered in all these widely separated countries, except perhaps New Zealand and the islands of the Pacific; and that along the course of their cieposit from Turkestan to Brittany, from China to Peru, you may trace the emigration march of the earliest inhabitants of the globe.

In support of this theory, the jade ornaments of Central and Southern America have been cited-coupled with our own inplements and those of Alaska and Siberia, plainly as it was alleged witnessing to the stream of migration from China through Siberia, the Alaskan peninsula, down 
the west coast of America to and beyond the Isthmus of Panama.

Unfortunately this fascinating thecry, in so far as it made Asia the home of American jade, may be said to have been conclusively disproved by the discovery of the half worked jade boulders of Alaska and of British Columbia.

Ever since the first gold excitement upon the Fraser, celts of this material have been met with in the placer diggings, and occasionally associated with them, small boulders have been found with one or more long grooves cut in them.

These were generally supposed to be hammers or pestles, and the grooves were thought to have been made to secure a good grip.

As they were clumsy looking object, and frequently of very poor material, they do not seem to have attracted much attention, or to have been prescrved like the more beautiful and portable celts, but there can be no doubt they establish the locality whence these implements were derived. For they are examples of the original pcbbles out of which the celt was cut, and have either been lost, or perhaps in some cases abandoned as unsatisfactory by their possessors.

Subsequently similar specimens have been obtained from the sitcs of old Indian villeges and burying grounds in the same district, and it may be considered as an cstablished fact that here alone jade has been found in sufficient quantities to provide all the manufactured implements met with among the Indians. Its occurrence has probably always been very local, confined to the beds of some few streams, but where it has been discovered there is evidence to show that it has been seized upon with avidity and transformed into the tools we now find.

In the small collection before you, which I have been enabled to make during my six years residerise in B. C., chiefly through the kindness of generous iriends, you will see every stage through which the mineral passes from the water 
worn pebble to the perfect celt. These specimens are mainly from the Fraser and Thompson rivers or their streams, which I conceive in the absence of ary contrary evidence to have been the sole sources of the B. C. jade.

There are no signs of its occurrence among the islands of the coast, except as a manufactured article, though I had imagined a certain inferior brown variety which I obtained from Alert Bay, and further specimens of which will be seen in the Museum collection as coming from Saanich, might have had an independent origin. It is certain that the Coast Indians valued the material highly and would avail themselves of anything like a local deposit that they could meet with.

Another reason for confining the source of jade to the above localities, and one which I think is well worth considering in its bearing on the wid. question of its general distribution is the diminution in size of the pieces the farther off they are discovered from these regions. This fact struck me as being very noticeable, the coast pieces are all smaller than those of the interior, and so far as I know none of the half worked boulders have been discovered at any distance from the supposed site of the deposit.

Now Lieut. Emmons of the U. S. Navy, who has made very careful investigation into the occurrence of jade in Alaska, has also obtained one or more large half worked boulders there. This would be quite in accordance with the theory that the size of the implement enables one in some degree to form an estimate of its proximity to the home of the mineral, since there is every reason to believe that the source of Alaskan jade is within that territory, and independent from our own.

Of course small articles may be met with near the nlace of their manufacture, for the material was too valuable for small chips of a good piece to be thrown away, it is not therefore the presence of small implements, so much as the 
aainly which have slands I had tained e seen might Coast themmect

to the con. al disher off me as than e half from

made de in rorked ith the some me of at the depennlace le for is not as the

absenc: of large ones that may be relied upon as an indica. tion ci remoteness from the source of original discovery.

And I think this view will be borne out by an examina. tion of such objects as have been discovered among prehistoric remains in Europe. Those which Dr. Schliemann unearthed upon the site of Troy are quite insignificant in size from a British Columbian point of view.

It is very reasonable to suppose that the persons who discovered jade and worked it, should retain the finest tools, as there never seems to have been a suffieient quantity to reduce $i^{t}$ to a mere article of commerce, and that the smaller arit $\cdots$ table pieces would be coveted by, and bartered to neighbouring tribes, becoming more rare and precious the farther they were taken from homs, until at last by the reduction of constant usc, and by fresh subdivision due to breakage, by accident or on purpose, the chisel would become too small for anything but an ornament or charm, yet retaining a distinctly celt-like shape.

I believe it will also be found in support of the same vicw, that the smaller articles, those which are presumably remote from the locality in which thcy were first made, show most cvidence of care and finish in their manufacture, as if they had Luen constantly re-cut and polished up by their fortunate oses: sor.

The cii lis coast, so far as I an " $\mathrm{s}_{\text {, }}$ were chisels or celts. The method adopted in the.. 1 1 acturc was very ingenious and is well worth describing. The first discoverer of a large pebble or boulder, set to work to cut a groove across it parallel to its longest axis, as in No. 2. To this end he einployed a thong of deer hide and some wet sand, placing the stone upon his 1 ises, or upon a wooden block, and holding one end of the "rog $\mathrm{g}$ in each nand.

The the grooves. $\therefore$ ailernative method has been suggested of 
using a piece of pointed wood instead of a thong, but in the specimens which I have myself examined all the grooves are deepest towards their ends, which is indicative of the action of a taut string, whereas a wooden pointer would produce the contrary effect, a hollowing down in the centre of the groove, midway between its ends.

Both processes, however, may well have been applied to suit circumstances.

Having cut two of $t$ :rooves parallel to one another a ridge of jade would projer. ween them which was then broken off by a smart blow fru: a hammer.

No. 2 appears to have been abandoned for some reason after one groove had been cut, and that to an insufficient depth.

Nc. 3, which is of material that would have made a very beautiful tool seems to have been lost just before ready for detaching a flake, and No. 4, which must have once been a splendid possession to its owner has had at least six slabs cut off it.

The polishing and sharpening of the tool would not appear a very difficult matter after the fragment was once successfully detached. No. 6 , thoug 1 of impure material, is a good specimen of a roughly finished piece, showing as it does the convex curvature left by the grooving process.

The original maker of the tool so long as he got a good cutting edge, would not trouble much about polishing the sides as the reduction in size consequent on taking off the fractured portions and groovings would be considerable, and his object would be to have as broad an edge and as substantial a handle as possible.

It is noteworthy that unless the chisel be double edged, a rare form, there $i$. little or nothing done to the blunt end in the way of polish, beyond occasionally grinding a small facet for striking with a mallet, no doubt for fear of unnecessarily reducing the size of the instrumerit. 
Now what inferences may we fairly draw at the present very limited stage of investigation from the presence $c^{r}$ these implements.

First-It may be, I think, considered as good as proved. that they were not imported from Asia. It would be contrary' to all cxperience for savage nations to import raw materials, such as these boulclers, or even little pebbles like No. I, and if they had done so, the half worked article would have been found on the coast, and the highly finished tool in the interior.

Sccondly - It has not yet been, so far as I know, satisfactorily established where the Mexican or Southern American Jade came from, and until it is discovered on the spot in as rough a state as this, the inference would be far more fair that it came from here, than that it crosscd the sea from China.

But we must remember before hiü:tily adopting this con clusion, that the presence of similar grological conditions down the western coast of America, makes it highly probable that jade would be inct with occasionally throughout that region.

On the other hand, so far as I am aware, the Indians of Oregon and California have not preserved any traces of such discovery.

But whether or no southern jade was derived from a northern source, the puzzle remains; why do we find so widespread an admiration for so scarce a material?

Is it reasonable to suppose that it commended itself to numerous independent tribes, and that its adoption by these was quite uninfluenced by connection of race?

Could so obscure a mincral, according to the ordinary law of chances, be calculated to present itself for trial to the primitive inhabitants of many distant countrics?

Is it not more probable that some previous experience of its qualitics, accompanied the earlicst emigrants to this 
coast, and that they soon recognized pebbles of a similat character.

The religious or quasi-religious and asthetic repute of jade has been left unnoticed. As regards the former, it is worthy of remark that it secms to have increased in inverse ratio to the use of the matcrial for implements.

No doubt a recollection of its value would survive the time of its use, and this remote tradition would be sufficient, coupled with its somewhat unusual appearance to invest it with supernatural attributes.

Its religions repute is then, I take it, more an indication of its antiquity and scarcity than of anything clse.

Aesthetically, it has becn held in higher esteem by the (hinese than any other race. They have had access to the greatest supply, and that of the choicest quality: They too, are, and hale ever been noted for their reverence of anticuity; and it is quite in accord with their ant principles that they should enlarge extravagantly upon the beauties of a substance which, for perhaps, some othed reason, their ancestors had valued.

Of course these theories are merely theorics, and perhaps in the present limited state of our knowledge, it wouk be better not to advance them, but unless public attention be drawn by theorising, to the extraordinary interest of this subject, it is to be feared that all data for founding salfer conclusions will be dissipated and lost.

We cannot afford to surrender a single piece of jade from this Province, and 1 hope all who are interested in the country will do their best to preserve this, one of its most curious antiquitics. 
milar

Ite of

it is

iverse

e the cient, est it ation

" the

o the

too, duity. they tance had

haps

(i) be

$n$ be

this

con.

from

intry

rious 
-)
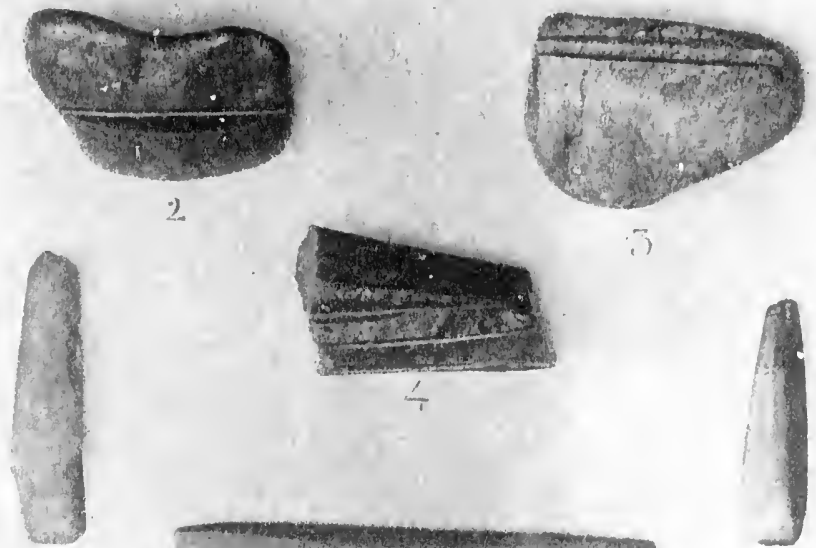

i)
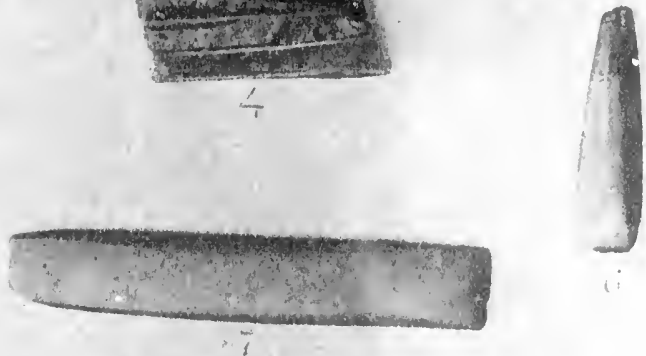

fe

III

111

ar

el
ci

j
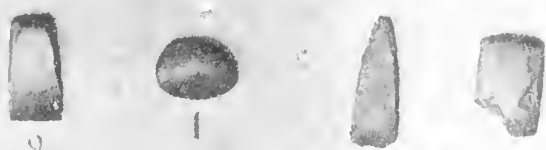

())

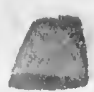

(i.)
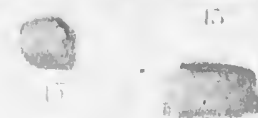

(s)

k

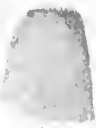

m

'I'

a

mi 


\section{JAIEE IMPLIEMENTS FOUNI) IN B. C.}

1. Jate pebble, kept as a charm by Thompson 12. chief; blue-green mottleil.

2. Jate bonkler, fr, vicinity of Lytton ; (at junetion of Fraser R. and Thompsem 1i.) Aark grey greein.

3. Tate bonkler, fr. Fraser IR. above Yale; white, with green veins and llocks. There is : 1 eorresponding groove on the nuder side, leaving a ridge !, inch diam. to be broken.

t. Jakde loulder, fr. Fraser li. alove Ynle, fomm in a ilacer elaim 12 foet bolew the surface; dark emerald green, very transluecent. A large nomber of tents, fertainly seven, have foren ent from this piece.

5. Celt, fr. Lytton; light gretn. depply grooved on inner side.

6. Celt, origin meertain, lont probably Fraser R.; sap-green, truns. lucent, slight growve on onter side.

7. Celt, fr. Kinnloops; very dark green to bhok, almost opment, small aroose on uper side, sharpened at both ends.

8 Colt, fr. Victorin; gresen, with black veining, a thick tool with grooves on inner sicle. This was dug up in a garden in the centre of the city.

9. Celt, fr. Alert Bay, Vunemwor Is.; dark grey green, mottled with black. 'This tool has bee'n much re-ent, and shows no greoring.

11. Celt. \{r. Mayne Is.; dark green to black, apparently very old, and muele woither worn, foumd associated with obsidim arrow-heads of the earliest typer, at a comsiclerable depth.

11. Celt, fr. Mnyne Is ; light green to white; muel a e-eut no all sides.

12. Cell, fr. Mayne In.; opaque, light brown stone, but apparently jade. The lontt end of a longer toen which has been sharpened down to its present size.

13. Celt, fr. Mayne Is, almost black, with deep green and reddish markings. Like the list this is evidently the worn down butt of a larger tool.

14. Half celt, liroken, fr. Mayne Is.; mottled grey-green. This is of atu aphatently nephritio stome, lut very impure; it has broken transversely.

15. Celt, broken pieve of the sharpened ond, from Waynes Is.: seagreen, more tronslueent than ustuil, splinters, laminnted, whieh has ceacest ifs fracture.

Iti. IIalf ('alt, broken, fr. Mayne Ls.; greenisle gres, slarp ridges betwern double growsings on both sides. Has apparenty been burnt.

17. Spear-beid, hroken, fr. Mayne Is.: dark treen, with lighter streaks. Evitently this wis made ly a thint-worker : it was fomel with So. 10, and is the inly one that hat come to my netiec.

18. Sinee the foregoing paper was written, I have ohtained a very large bonlder, fombl with a depessit of stone implements, imeluding stene vessols of a steatite or roap-stone, netar the confluence of the Friser and Thompson Rivers. It is too large to have been earried far. and no donbt hat been treasured for the murpese of eutting inter teols. It is of at pale green nephrite, and weighs 23 pomels. 


\section{BI R DS}

\section{-OF- \\ British Columbia.}

There present a list of the birds of the Province, which is complete so far as the information at hand can make it.

It is more than probable, however, that future observations will add to its numbers, as the extreme northern and north-eastern portions of the Province still remain unexplored, and some species which cross the continent from Hudson's Bay, may be claimed as accidental visitants here, and also a few which are now ascribed entirely to Alaska, may be found. to extend their range into this Province, in fact one of these, the Irory Gull, has already been taken here.

\section{JOHN FANNIN,}

Curator Provincial Museum.

Western Grebe, Achmophorus Occidentalis.

Clark's Grebe, Echmophorus Clarkii.

Holboell's Grebe, or Red-necked Grebe, Colymbus: Hollowlii. Horned Grebe, Colymbus Auritus.

American Eared Grebc, Colymbus Nigricollis Californicus. Pied-billed Grebe, Podilymbus Podiceps.

Loon, Great Northern Diver, C'rinator Imber.

Black-throated Loon, Urinator Articus.

Pacific Loon, Urinator Pacificus.

Red-throated Loon, Urinator Lamme.

Tufted Puffin, Lunda Cirrhata. 
Rhinoceros Auklet, Cerorhinca Monocerata.

Cassins Auklet, Ptychoramplus Alenticus.

Ancient Murrelet, Synthlihoramphus Antiquus.

Miarbled Murrelet, Brachyramphus Marmoratus.

Pigeon Guillemot, Cepplius Columba.

California Murre, Uria Troile Californica.

Ivory Gull, Gazia Alba.

Pacific Kittiwake, Rissa Tridaclyla Pollicaris.

Glaucus-winged Gull, Larus Glaucesens.

IVestern Gull, Larms Occidcntalis.

which ake it. serva$\mathrm{n}$ and lored, dson's also a found. these,

גseum.

olbotii.

rmicus.

American Herring Gull, Larus Argrentatus Smithsomiamus.

Pallas's Gull, Larus Cachinnans.

California Gull, Larus Californicus.

Ring Billed Gull, Larns Delazarensis.

Short-billed Gull (Mew Gull), Larus Brachyrhyucus.

Heerman's Gull, Larus Hecrmanii.

Franklin's Gull, Larms Franklinii.

Bonaparte's Gull, Larns Philadelphici.

Arctic Tern, Slerma Paradisca.

American Black Tern, Mydrochelidon Nigra Surimemensis

Black-footed Albatross, Diomedea Nigripes.

Short-tailed Albatross, Diomedea Albatrus.

Pacific Fulmar, Fulmerus Glacialis Glupischa.

Fork-tailed Petrel, Occanodroma Furcata.

Leach's Petrel, Oceanodroma Leucorhoa.

White-crested Cormorant, Phalacrocorax DilophusCincimatus.

Violet-green Cormorant, Phulacrocorax Pclagicus Robustus.

American White Pelican, Pclecamus Erythrorhynchos.

California Brown Pelican, Pelecanus Californicus.

American Merganser, Merganser Americanus.

Red-breasted Merganser, Merganser Serrator.

Hooded Merganser, Lophodytes Cucullatus.

Mallard, Anas Boschis.

Blue-winged Teal, Anas Discors.

Cinnamon Teal, Anas Cyanoptera. 
Green-winged Teal, Anas Carolinensis.

Gadwall, Anus Strepera.

American Widgeon, Anas Americana.

Shoveller, Broad-bill, Spalula Clypeata.

Pintail, Sprigtail, Dafila Acuta.

Wood Duck, Aix Sponsa.

Pochard, Red-head, Aythy' Americana.

Canvas-back, Avthyo Vallisneria.

American Scaup, Blue 13ill, Aythya Marila Nearctica.

Lesser Scaup, Avthya Affinis.

Ring-neck, Aythy'ct Collaris.

American Golden-eyc, Glancionctta Clang'ula Americama.

Barrow's Golden-eye, Glancionetta Islandica.

Buffle-head, Butter-ball, Charitonetta Albcola.

Long-tailed Duck, Old Sqaw, Clangula Hycmalis.

Harlequin Duck, Mistrionicus Histrionicus

Pacific Eider, Somateria z'. Nigra.

American Scoter, Oidemia Americana.

White-winged Scoter, Oidemia Deglandi.

Surf Scoter, Coot, Oidcmia Perspicillata.

Ruddy Duck, Erismatura Rubida.

Lesser Snow Goose, Chen Myperborea.

Ross's Snow Goose, Chen Rossii.

American White-fronted Goose, Anser Allifrons Gambcli. Canada Goose, Branta Canalensis.

Hutchin's Goose, Branta Canadensis Hutchinsii.

White-cheeked Goose, Branta Canadensis Occidentalis.

Cackling Goose, Branta Canadensis Minima.

Black Brant, Branta Nigricans.

Whistling Swan, Olor Columbianus.

Trumpeter Swan, Olor Buccinator.

White-faced Glossy Ibis, Plegadis Guarauna.

American Bittern, Stake Driver, Botaurus Lentiginosus.

Great Blue Heron, Ardea Herodias

Snowy Heron, Ardea Candidissima. 
Little Brown Crane, Grus Canadensis.

Sandhill Crane, Grus Mexicana.

Virginia Rail, Rallus Virginianus.

Carolina Rail, Soro, Porzana Carolina.

American Coot, Fulica Americana.

Red Phalarope, Crymophilus Fulicaruıs.

Northern Phalarope, Phalaropus Lobatus.

Wilson's Phalarope, Phaluropus Tricolor.

Wilson's Snipe, Gallinago Delicata.

Long-billed Dowitcher, Red-breasted Snipe, Macroramphus

Scolopaccus.

Knot, Robin Snipe, Tringa Canutus.

Pectoral Sandpiper, Tringa Maculata.

Ba'-1's Sandpiper, Tringu Bairdii.

I Sandpiper, Tringa Minutilla.

K. - sdcked Sandpiper, Tringa Alpina Pacifica.

Semipalmated Sandpiper, Ereunetes Pusillus.

Western Sandpiper, Ereunetes Occidentalis.

Sanderling, Calidris Arenaria.

Marbled Godwit, Limosa Fedoa.

Greater Yellow-legs, Totanus Melanoleucus.

Yellow-legs, Totanus Flavipos.

Solitary Sandpiper, Totanus Solitarius.

abcli

Cinnamon Solitary Sandpiper, Totanus Solitarius Cinnamomeus.

Wandering Tatler, Heteractitis Incanus.

Buff-breasted Sandpiper, Tryngitcs Subruficollis.

Spotted Sandpiper, Actitis Macularia.

Long-billed Curlew, Numenius Longirostris.

Hudsonian Curlew, Numenius Hudsonicus.

Black-bellied Plover, Charadrius Squatarola.

s merican Golden Plover, Charadrius Dominicus.

Kil'deer Plover, Egialitis Vocifera.

Sem palmated Plover, Egialitis Scmipalmata.

Surf Bird, Aphriza Virgata. 
Turnstone, Arcnaria Interpres.

Black Turnstone, Arenara Melanocephala.

- Black Oyster-catcher, Hamatopus Bachmani.

Mountain Partridge, Quail, Orcortyx Pictus.

Californian Partridge, Callipepla Californica.

Sooty Grouse, Dcudragapus obscarus fuliginosus.

Richardson's Grouse, Dendragapus Richardsonii.

Franklin's Grouse, Dendragapus Franklinii.

Canadian Ruffed Grouse, Bonasa Umbellus Togata.

Gray Ruffed Grouse, Bonasa Umbelins Umbelloides.

Oregon Ruffed Grouse, Willow Grousc, Bonasa Uimbellas Sabina.

Willow Ptarmigan, Lagopus Lagopus.

Rock Ptarmigan, Lagopus Rupeslrus.

White-tailed Ptarmigan, Lagopus Leucurus.

Columbia Sharp-tailed Grouse, Pcdiococtes Phasiancllus Columbianus.

Sage Grouse, Centrocercus Urophasiumus.

Band Tailed Pigeon, Columba Fasciata.

Mourning Dove, Zenaidura, Macroura.

California Vulture, Pscudogryphis Californiamis.

Turkey Vulture, Cathartes Aura.

Marsh Hawk, Civcus Mudsonius.

Sharp-shinned Hawk, Accipiter Vclox.

Cooper's Hawk, Accipiter Cooperi.

Western Goshawk, Accipiter Atricapillus Striatulus.

Western Red-tailed Hawk, Buteo Borealis Calurns.

Red-breasted Hawk, Butco Lincatus Elegans.

Swainson's Hawk, Buteo Szvainsoni.

American Rough-legged Hawk, Archibuteo Lagopus SanctiFohamis.

Golden Eagle, Aquila Chrysinetos.

Bald Eagle, Haliaetus Lencocephulus.

Prairie Falcon, Fulco Mexu:anus.

Duck Hawk, Fulco Percgrimus Anutum. 
Peale's Falcon, Falco Percgrinus Pealei.

Pigeon Hawk, Falco Columbarius.

Black Merlin, Falco Columbarius Suckleyi.

Richardson's Merlin, Falco Richardsonii.

American Sparrowhawk, Falco Sparverius.

American Osprey, Pandion Haliaetus Carolinensis.

American Long-eared Owl, Asio Wilsonianus.

Short-eared Owl, Asto Accipitrinus.

Great Gray O;vl, Scotiaptex Cinereum.

Saw Whet Owl, Nyctala Acadica.

Kennicott's Screech Owl, Megascops Asro Kennicotii.

Western Horneu Owl, Bubo Virginianus Subarclicus.

Dusky Horned Owl, Bubo Virginianus Saturatus.

Snowy Owl, Nyctea Nyctea.

American Hawk Owl, Surnia Ulula Caparoch.

Burrowing Owl, Speotyto Cunicularia Hypogaa.

Pygmy Owl, Glaucidium Gnome.

California Cuckoo, Coccyzus Americumus Occidentalis.

Belted Kingfisher, Rervle Alcyon.

Northern Hairy Woodpecker, Iryobates Villosus Leucomelus.

Harris's Woodpecker, Dryobates V'illosus Harrisii.

Downy Woodpecker, Dryobates Pubescens.

Gairdner's Woodpecker, Dryobates Pubescens Gairdnerii.

Batchelder's Woodpecker, Dryobates Pubescens Oroecus.

White-headed Woodpecker, Fenopicus Albolurvatus.

Artic Three-toed Woodpecker, Picoides Arcticus.

Alpine Three-toed Woodpecker, Picoides Amercanus Dursalis.

Red-naped Sapsucker, Sijhyrupicus Varins Nuchalis.

Red-breasted Sap-sucker, Sphyrapicus Ruber.

Williamson's Sap-sucker, Sphyrapicus Thyroideus.

Pileated Woodpecker, Ceophlieus Pileatus.

icwis's Woodpecker, Melanerpes Torquntus.

Flicker, High.holder, Colaptes Auratus.

Red-shafted Flicker, Colaples Cufer. 
Northwestern Flicker, Colaptes Cafer Saturatior.

Nighthawk, Chordeiles Virginianus.

Wes

Bull

Western Nighthawk, Mosquito Hawk, Chordeiles VirginiBrev anus Henryi.

Black Swift, Cypseloides niger.

Vaux's Swift, Cheetura Vauxii.

Black-chinned Hummingbird, Trochilus Alexandri.

Rufous Hummingbird, Trochilus Rufus.

Allan's Hummingbird, Trochilus Alleni.

Calliope Hummingbird, Trochilus Calliope.

King Bird, Tyrannus Tyranms.

Gray Kingbird, Tyranums Dominiccusis.

Arkansas Kingbird, Tyrammis Verticalis.

Say's Phœbe, Sayornis Saya.

Olive-sided Flycatcher. Contopus Borcalis.

Western Wood Pewee, Contopus Richardsonii.

Baird's Flycatcher, Empidonax Bairdii.

Western Flycatcher, Empidoinax Difficilis.

Little Flycatcher, Empidonax Pusillus.

Traill's Flycatcher, Empidonax. Pusillus Trailli.

Hammond's Flycatcher, Empidonax Hammond.

Pallid Horned Lark, Otocoris Alpestris Lcucolcema.

Streaked Horned Lark, Otocoris Alpestris Strigata.

Dusky Horned Lark, Otocoris, Alpestris Merrillii.

American Magpic, Pica Pica Iludsonica.

Steller's Jay, Cy'anocitta Stelleri.

Black Headed Jay, Cyamocitta Stelleri Annceten.

Oregon Jay, Perisoreus Obscurus.

Northern Raven, Corvus Corax Principalis.

California Crow, Corzus Americanus Hesperis.

Northwest Crow, Corvus Caurinus.

Clarke's Nutcracker, Picicorvus Columbianus.

Cowbird, Melothrus Ater.

Yellow-headed Blackbird, Xanthocephaliss Xinthocephalus.

Red-winged Blackbird, Agelaus Phenicens.

Eve

Pine

Caii

Cas

Am

W's

Gra

$\mathrm{He}$

$\operatorname{Rec}$

Am

Pin

Snc

La]

$\mathrm{Ma}$

$\mathrm{Ve}$

Wo

Sa

W

In

$\mathrm{Ga}$ 
Western Meadow Lark, Sturnella Magna Neglecta.

Bullock's Oriole, Ictcrus Bullocki.

Brewer's Blackbird, Scolecophagus Cyanocephalus.

Evening Grosbeak, Coccothraustes Vespertinus.

Pine Grosbeak, Pinicola Enucleator Canadensis.

Caiifornia Purple Finch, Garpodacus Pu pureusCalifornicus.

Cassin's Purple Finch, Carpodacus Cassini.

American Crossbill, Loxia Curvirostra Minor.

W'hite-winged Crossbill, Loxia Leucoptera.

Gray-crowned Leucosticte, Leucosticte Tcphrocotis

Hepburn's Lcucosticte, Gray-crowned Finch, Lencosticte Tephrocotis Littoralis.

Redpole, Acanthis Linaria.

American Goldfinch, Spinus Tristis.

Pine Siskin, Pine Linnet, Spinus Pinus.

Snowflake, Plectrophenox Nizalis.

Lapland Longspur, Calcarius Lapponicus.

Macown's Longspur, Rhynchophanes Macouni.

Vesper Sparrow, Poocates Gramineus.

Western Vesper Sparrow, Bay-winged Bunting, Poocatc Gramineus Confinis.

Sandwich Sparrow, Ammodramus Sandzichensis.

Western Savannah Sparrow, Ammondramus Sandwichensis Alandinus.

Intermediate Sparrow, Zonotrichia Intermedia.

Gambel's Sparrow, Zonotrichia Gambeli.

Golden-crowned Sparrow, Zonotrichia Coronata.

Western Tree Sparrow, Spizella Monticola Ochracea.

Western Chipping Sparrow, Spizella Socialis Arizona.

Brewer's Sparrow, Spizella Brezveri.

Slate-colored Junco, Funco Hyemalis.

Oregon Junco (Snow-bird), Funco Hyemalis Oregonus.

Rocky Mountain Junco, Funco Hyemalis Schufeldtii.

Rusty Song Sparrow, Melospiza Fasciata Guttata.

Sooty Song Sparrow, Melospiza Fasciuta Rufina. 
Lincoln's Sparrow, Mclospiza Lincolnii.

Forbush's Finch, Mclospiza Lincolnii Striata.

Townsend's Sparrow, Passcrella Iliaca Unalasche'us.s.

Spurred Towhee, Pipilu Maculatus Megalenyx.

Oregon Towhee, Pipilo Muculatus Orcgomus.

Black-headed Grosbeak, Matria Mclanocepholu.

Lazuli Bunting, Passerina Amerma.

Louisiana Tanager, Pircungu Luedozicranct.

Purple Martin, Progue Sullis.

Cliff Swallow, Pitrochelidon L, mnitions.

Barn Swallow, Chelidon Erythrogerster.

Tree Swallow, Iv hite-bellied Swallow, Tuchycincla Bicolor.

Violet-green Swallow, Tachycincta Thulussinu.

Rough-winged Swallow, Stelgidoptery. Somipenmis.

Bohemian Waxwing, Ampilis Gurmlus.

Cedar Bird, Ampelis Cedrormm.

Northern Shrike, Butcher-bird, Lamius Borculis.

White-rumped Shrike, Lanius Ludoricianus Evirubitorides.

Red-cyed Vireo, Vireo Olizacus.

Western Warbling Vireo, I ireo Glizus Szeuinsomii. •

Warbling Vireo, Vireo Gil:us.

Cassin's Vireo, Virco Soliturius C'ussmi.

Plumbeous Vireo, Vireo Solitarius Plumbers.

Orange-crowned Warbler, Helminthophila C'clute.

Lutescent Warbler, Helminthophila Celute Lutescens.

Yellow Warbler, Dendroica Estiza.

Western Yellow Warbler, Dendroicu Estiza Mercomii.

Myrtle Warbler, Dendrovica Corronuta.

Audubons Warbler, Dendroica Alutuboni.

Black-throated Gray Warbler, Dendroica. Nigressens.

Townsend's Warbler, Dendrevica Toaensendii.

Hermit Warbler, Western Warbler, Dendrovica Ocridentalis. Grinnell's Water-thrush, Scimrus Nozechoracensis Notubils.

MacGillivray's Warbler, Gcothlypis Macgilliz'uy'.

Western Yellow-throat, Geothlypis Trirhas Ocridentalis. 
Long-tailed Chat, Ieteria Irirens íongricuntu.

Pileolated Warbler, Sylizania Pusilla Pileolata.

American Redstart, Sctophaga e.:'ticilla.

American Pipit, Anthus Pensilamicus.

American Dipper, Cinclus llexicunus.

Catbird, Craleoseople's C'arolinemsis.

Rock Wren, Sulpiuctes Obsoletns.

Vigor's Wren, Thryothorus Besilkii Spilums.

Parl:man's Wren, Troglodyte's Acdon P'ortimanii.

Weswn Winter Wren, Thoglodytes ilicmalss Pacitions.

Longr-billed Marsh Wren, C'istotionus Polustris.

Tule Wren, Cistothorws Palustris Paludicola.

Rocky Mountain Creeper, Cirthia Familiaris Hontanu.

Californian Creeper, Certhia Familiaris Occidenteris.

Slender-billed Nuthatch, Sitta Carolinensis Aculecuia.

Red-breasted Nuthatch, Silta Canadensis.

i'ygmy Nuthatch, Sitter Premere.

Mountain Chickadec, Parus Germbeli.

Oregon Chickadec, I'arus . Hricupillus Occidintalis.

Long-tailed Chickadee, Purus Arricupillus sitemtrionalis.

Chesnut-backed Chickadee, Parus Rufiscens.

Bush Tit, Paltrifarws Minimus.

Western Golden-crowned Kinglet, Regulus sirlrupu Oliz'ace"ts.

Ruby-crowned Kinglet, Regulus Calendula.

Townsend's Solitaire, Myodestes Tozensculii.

Willow Thrushi, Timblus Fuscesens Salicicolus.

Russet-backed Thrush, Turdus Ustulatus.

Dwarf Hermit Thrush, Turdus Aomalaschlier.

Western Robin, Mcrula Migratoria Propingua.

Varied Thrush, Swamp Robin, Icsporocichla . Viz'in.

Western Blucbird, Sialie Mexrena.

Mountain Blucbird, Sialia Aretica 


\section{I, E $($ E, $\mathrm{N} D$ \\ (I) $1 \mathrm{HH}-\ldots$}

\section{Cowitelnan Indians.}

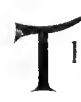

llk subjoined lesenel of the cowitchan landians, called

by themselies the Whull-e-mooch or dwellers by l'uget Sound, seems to me worth preserving. I give it at I heard it from the Indians in ass a:

"There was a time very lons aso, our fathers tell ws, when the Whull-e-mooch lised a lons way further south thas we, their children, do now. Northward the whole country. from the sea to the farthest monntains, wav corered with suow and ice, so deep that the heat of summer failed to melt it. The old folk tell us that their fathers clicl not like the land they lised in and wished to move away, hut were at a loss where to go to. Southward lived a people whom they feared becauc they were stronger than they, our fathers, were; nortlumarel the snow and ice prevented them moving. While they were discusing what to do, the "spaul" (raten) came seldelenly amonest them. After listening to their griesances, he saicl 'I will soon settle that difficulty. So saying, he turued all the snow and ice into "l'e kulkum, or mountain gobts, and sent them to make their home in the fastness of the hishest momntains, where there would be food for them, while their wool would make clothing for the - Whull-e-mooch' for ever. After this transformation of snow into soats, the climate became warmer, and the country dryer, which enabled the Whulle-mooch to move northwarel 


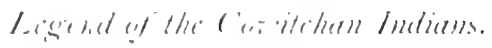

(1) where we, their childen, now live and hate liscel cere since."

This lesend is the more remarkible as the mistationppoken of seem to hate taken platee in or about the slacial period. Whether these migrations atemally took place an

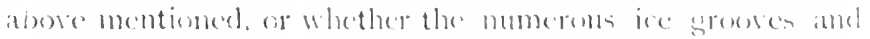

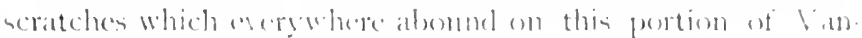

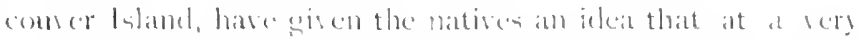
remote perient the whele land was full ot -now and ier, is mot .1p)incint.

laking the lesend $m$ its -implicity the mforemes perhapes in that this part w the X. A. Continent was inhabited at a time when an aretic climate presaled much further south than at preant, that the furlians believe the change in climate to hase been wrousht for their benedit by "spatul, the rasen. in whese imase thene people belices that the Almierlet? in in the habit of appearing to men

II ible soats still abouml on the mountain flopes of the coilit rimuse.

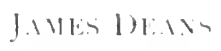

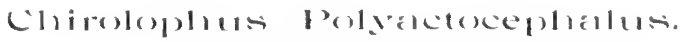

A specimen of this blenny was ient me from . Alert bity in Norember last ; it has mot previously been recorded south of Alaska, and no full dencription of it hawing ener been published, I sent the following to t)r. Jordan, the well kmown authority on American fishes.

Body elongate, compressed, 14, inches lons Eyes apporoximate; no lateral line scales deeply imbededed. 


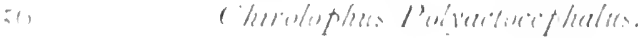

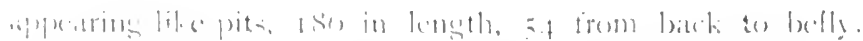

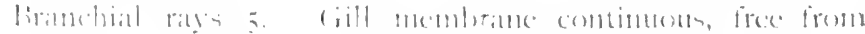

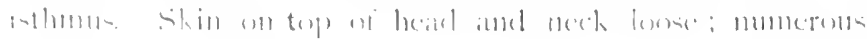

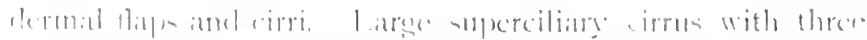

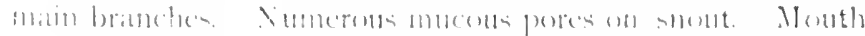

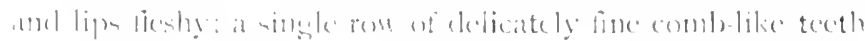

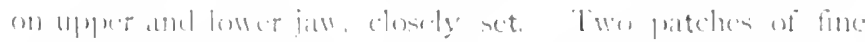

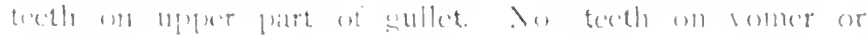
pialiatian.

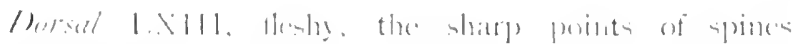

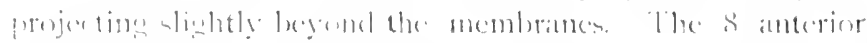

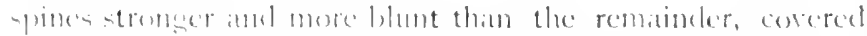

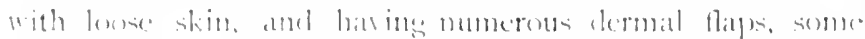

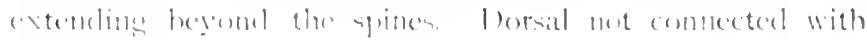
the caimlal

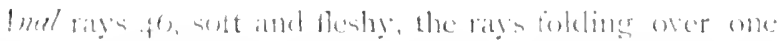

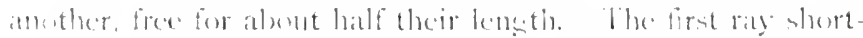

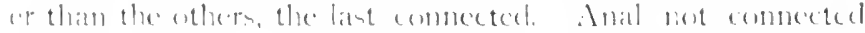

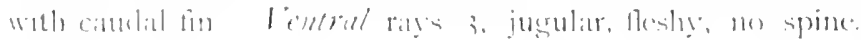

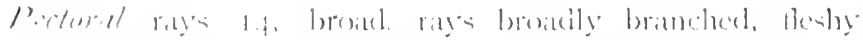

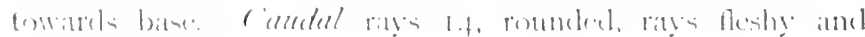
loratlly lowarherl.

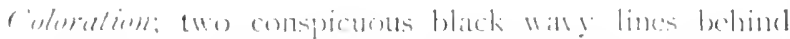

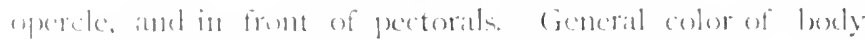

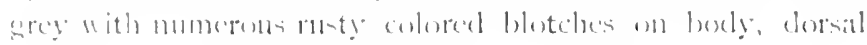

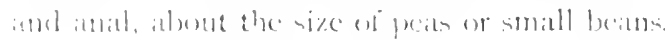

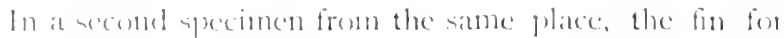

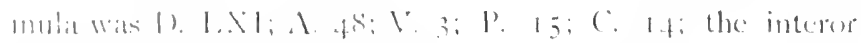

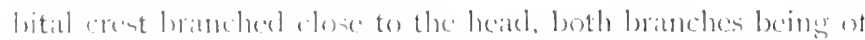
the simbe size, and the dermal thape on doreal fin and neck ucre more mumeros and longer.

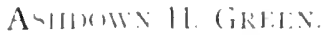




$$
1
$$




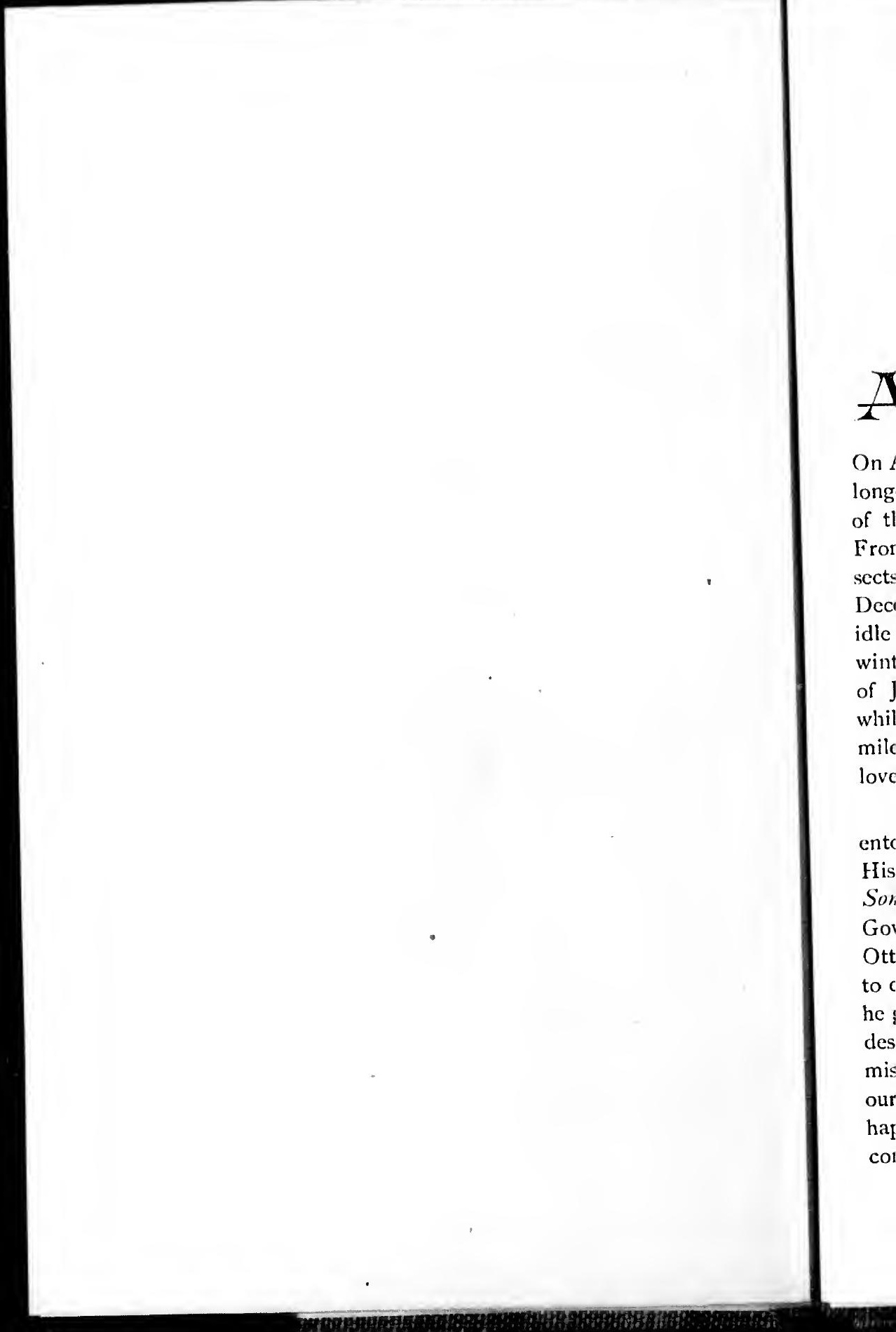




\section{ENTOMOLOGY.}

\section{TLTHOUGH Vancouver Island is an excellent field for Entomology, very little collecting was done here in I 890 . It is hoped that more will be done this year.} On April 3 rd the first eight captures at an clectric light, belonged to as many different species. This gives some idea of the number of varicties likely to reward diligent search. From the advent of Feralia jocosa, one of our carliest in. sects to the appearance of $C$. Bruceata and $H$. Defoliaria, in December, the Victorian entomologist need never have an idle day. $V$. Antiopa and $P$. Alulanta awake from their winter sleep and sail about our strects in the first sunny days of January. In May, fritillaries swarm upon Beacon Hill, while $C$. Gigers may casily be caught on the mountains, a few miles to the North. Blues abound upon the coast and the lovely Argynnidi are sufficiently common.

Good work has becn done by the Socicty's members in entomology this past year, notably the completion of the Life History of the Vancouver Island Oak-tree looper, (Ellopia Somniaria, Hulst) in conjunction with Prof. James Fletcher, Government Entomologist at the expcrimental farm, Ottawa, who has thought the matter of sufficient importance to devote a lengthy article to it in his annual report, wherein he gives sound advice as to the most effective remedies for destroying this pest. It is sincerely hoped that the Park Commissioners will see the necessity of using every effort to save our shade trees in the Park, and not allow such desolation to happen as was caused last summer, when the Oak-trees were completely defoliated by this insect. 
Appended is a list of diurnal lepidoptera taken during 1890 in Victoria.

1. Papilio eurymedon.

2. do. arizonensis.

3. Parnassus clodius.

4. Neophasia menapia.

5. Picris pallida.

6. do. venosa.

7. Anthocharis ansonides.

8. do. stella.

9. Colias ariadne.

ı. Thecla melinus.

I I. Chrysophanus helloides.

12. Lycana antiacis.

13. do. neglecta.

14. do. sapiolus.

15. Argynnis bremnerii.

16. do. epithore.

17. do. zercne.

18. Melitaa taylori.

19. Grapla satyrus.

20. Vancssa antiopa.

21. do. californica. *

22. do. milberti.

23. Pyrameis atalanta.

24. do. cardui.

25. do. carye.

26. Limenitis lorquini.

27. Cononympha ampelos.

28. Pamphila agricola.

29. Nisoniades propertius.

*First reported capture of this insect on Vanoouver Island, and possibly the first in Canada. 


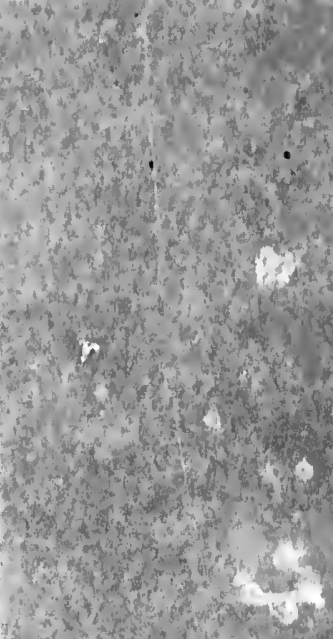

od, and

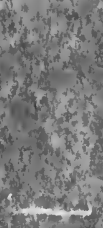

tons

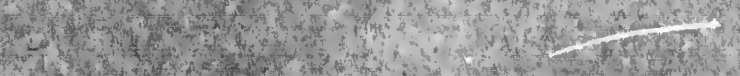


$2^{*}$

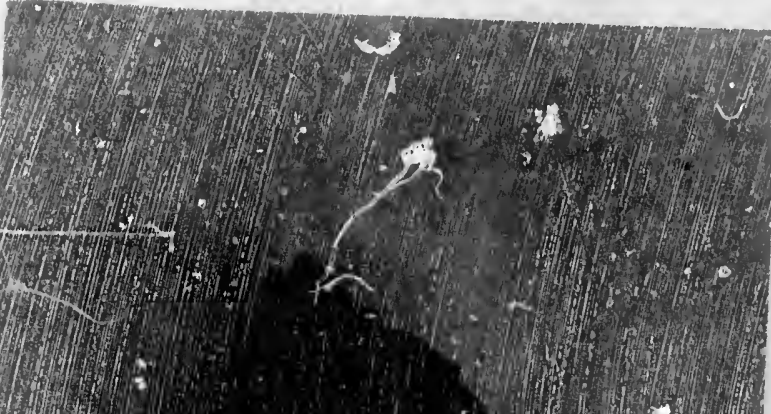

(1)

(.)

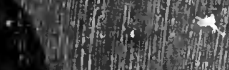

4.

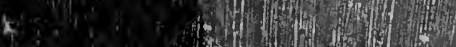

Ying

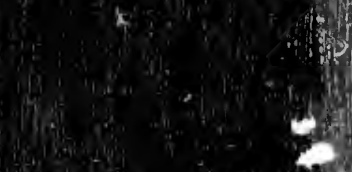

d)

4. (x)

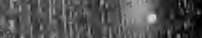

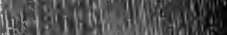

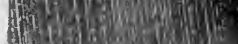

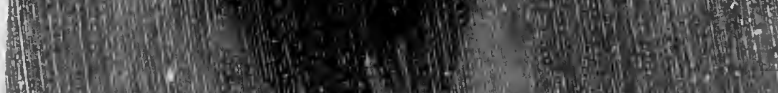

H J

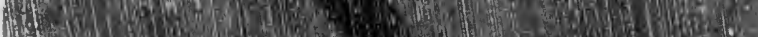

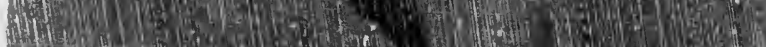
f We

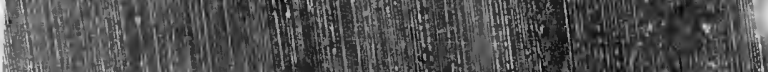

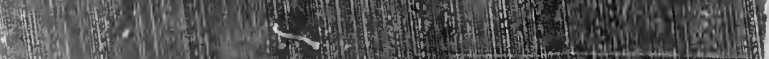
7. 5 (1) (1)

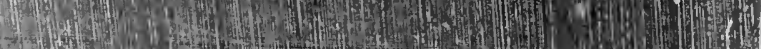
3.1.2.

fo

T1

$\mathrm{Fi}$

m

ru

be

$\mathrm{vi}$ 


\section{RHAMHHOCO'T'TUS RICHARDSONI,}

This little fish, until recently considered a rarity, is now found to be common in Victoria and Esquimalt Harbors. The description of it in Jordan and Gilbert's "Synopsis of Fishes of North America" is a good one; though to make it more perfect, I would add that is narrow oblique black band runs from the centre of the anal fin to the upper base of caudal, behind which band both the tail and thr caudal fin are of a vivid orange color, as are all the rest of the fins.

A. H. G.

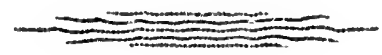

\section{THE SCORPION.}

In October last a small Scorpion was received from Mr. Bullock Webster, who found it at Keremeus, on the Similkameen river. I believe this to be the first one recorded in British Columbia, and indeed in Canada, thougr I an informer that they have been occasionally found on the Similkameen. The length of the pecimen is $1 \frac{1}{2}$ inches; the specics awaits identification.
A. H. G. 


\section{DONATIONS}

\section{To Provincial Museum}

BY MEMFERS OF THE SOCEFTY.

MR. HASELl :-Gairdner's Woodpecker, North Western Flicker, Oregon Towhce, Audubons Warbler, Ruby crowned Kinglet, Orange crowned Warbler, Oregon Junco, Harriss Woodpecker, Gold-winged Flicker.

MR. DAN BY: - Various insects.

Mr. Merrill:-Gebia Pugettensis.

Mr. Deans:-Fossil Astrea from Skidegate, 2 specimens of Nautilus, Trigonia \&c. from Q. C. I., skull of Haidah woman, skull found on Euclataw Plains, eight spear-heads and a jade hatchet from Shell Mounds, Cadboro Bay, stone hammer from Comox.

Mr Ashoown Green:-Cyclopterus spinosus, Sebastodes paucispinus, Jade Chisel, Cancer Magister, Cancer Productus.

Mr. C. P. Wolley:-Black Bear.

DR. Newcombe:-Mya truncta, saxidomus squalidus, Saxicava rugosa from raised beach near Ross Bay, and fossil nautilus from Cobble Hill, Mopalia ciliata, Mopalia lignosa, Pinnixafaba, Porcellana rupicola, Cancer productus, Heterograpsus nudus, Cancer magister, Fresh water shells from peat layer over Raised Beach, Trichocera Orcgonensis, Mytilimeria Nuttalli.

Mr. DE Blois Green:-A collection of Butterflies from Enderby and Sicamous. 
Mk. A. C. Houghton:-Oregon Jay, Gairdner's Woodpecker, Virginan Rail.

Mr. SPENCER, Alert Bay:-Cheirolophis polyactocephalus.

The following were obtained in Dredging Exped itions by the Society:-

estern

Ruby

regon

ser.

imens

:ull of Plains, Sliell omox. istodes Cancer

Saxi$r$, and ciliata, picola, Cancer $r$ over imeria from
I6 Large Star fishes, five undetermined species:-

2 Sea Pens.

Puncturella galcata.

Puncturella cucullata.

72 Pexten hastaus and P. mulidtus.

I Solen sicarius.

6 Galerus fastigiatus.

3 Crepidala navicelloides.

36 Terebralula transversa.

I Natica clausa.

I6 Priene orcgonensis.

3 Ccrostoma foliatumn.

4 Purpura dispata.

3 Kennerlia grandis.

Placuanomia macroschisma.

2 Psammobia rubrorudiata.

6 Trichotropis cancellata.

I Mya truncata, dead.

2 Trophon orphens.

I Glvcimeris generosa, dead.

Lacuna vincta.

Ventus kennerleyi.

Psephis Lordi.

Angulus modestus.

Macoma secta.

Macomu Nasuta.

Macoma inquinata.

Macoma inconspicua.

Beaver Lake. Ancylus, Limnea, Planorbis, Anodon. 
Natural Jfistory Socioty of British Columbia.

President........... Ashdown Green, C.E.

Vice-I'residents, ... I. I) Hasell, M.R.C.S. Eng.

Treasurer......... J. K. Worsfold.

Curator, ......... J. Fannin.

Secretary, ......... C. F. Newcombe, M. 1)., A berdecen.

Libratian, ........ E. Hasell, M.R.C.S., Hene

Ficl

Fin

Cire

(ive

(ire

Gre

Ilal

Ila

Ha

COMNITTEE.

O. C. Hastings, C. P. Woolley; Rex. A. Beanlands. (. Lowenbers.

MIFAIBIEST.

Anderson, 11: 13 comox.

Bailey, J ................. Victoriat.

Bailcy, J. S

Beanlands, Rer. A

Begbie, Sir M. B

Bogress, B

Borde, H

Brownlec, J. II

Brown, J.

Brady, J .

Campbell, 1). E

Carmichael, II

Cowper, II. II
$11 \mathrm{a}$

Hia

Ha

lin

IIt

Jel

Jac

$\mathrm{Jot}$

Ki

Ki

Ki

K

1 .

I.

M 
Dupont, Major

Victoriat

1)anlo; II. II

I) cains, J

Derereus, J

Dumbleton, II

IBberts, 1). M

Fannin, J

ricklling, I

French, J. G

Green, Asholown

Green, Pas: II

(ireen, Delilois

Enderly, 13.

Ereggory, J. 13

Victoria.

llall, bewis

Hamington, F. B. (C, M. I) Mcrill.

IIalhect, R. B

Shawnigan Lake.

Hitsell, E. S.

Victoria

Mlatings, $O$

llarris, I. A

Iongliton, J. E.

Shat nigum I ath.

1 lowghton, A

Jenne, Revel. I'

Victoria

Jackion, R, I:

Jones, $(\mathrm{F}, \mathrm{F}$

Keary, 11. 11.

Kingham, Rerd. II.

Victoria

Knisht, J. W'

Kecn, Revd. J. II

Missett, () ( 1

I. owenberes, (

Victoria.

Iopatceki, M.

('ilifornia.

1.cwis, H. I3.

Villoumar

Matthews, $1:$ II

Vicforia.

Mitymard, A. H.

Merrill, J.

Milne, (. 1., II. I) 
Musatt, lhos. NeW 11 (atsumbit

Nuir, A. . I Vis toriat

Helianh, (i. . I

Mareger, II, I)

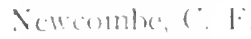

Nimsate, 1. B.

Pimker, II: (;

l'ike. 1

lindrict, . 1. I.

Survens. V'on. Arehreatens a

sprime 1

Shimer, l: Cintharr.

laylor, Res. I 11

vi(t)rit.

lialor, (s. II

lumer. J. 11

Makb. I, M N

II.ukfingtem, J I:

Wilker, Fi

Willemar. Rest Jat ier ('omms.

(I) ilun, i).

Visteriat

IIilley, ' I'.

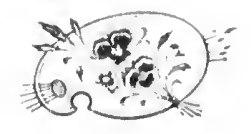




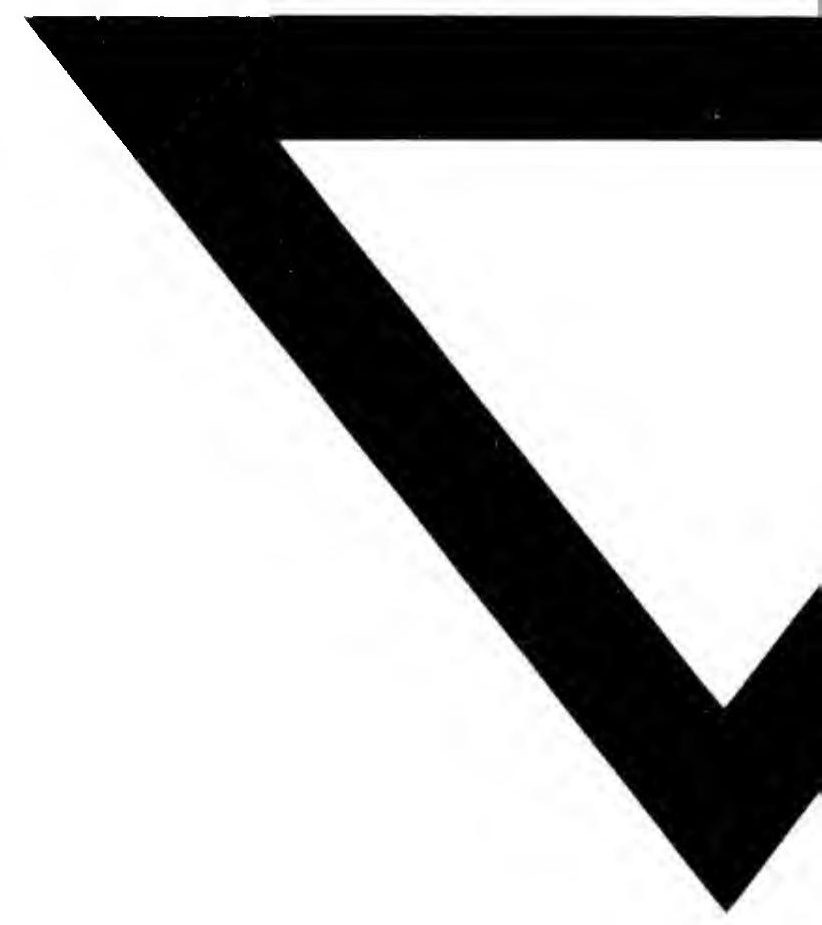




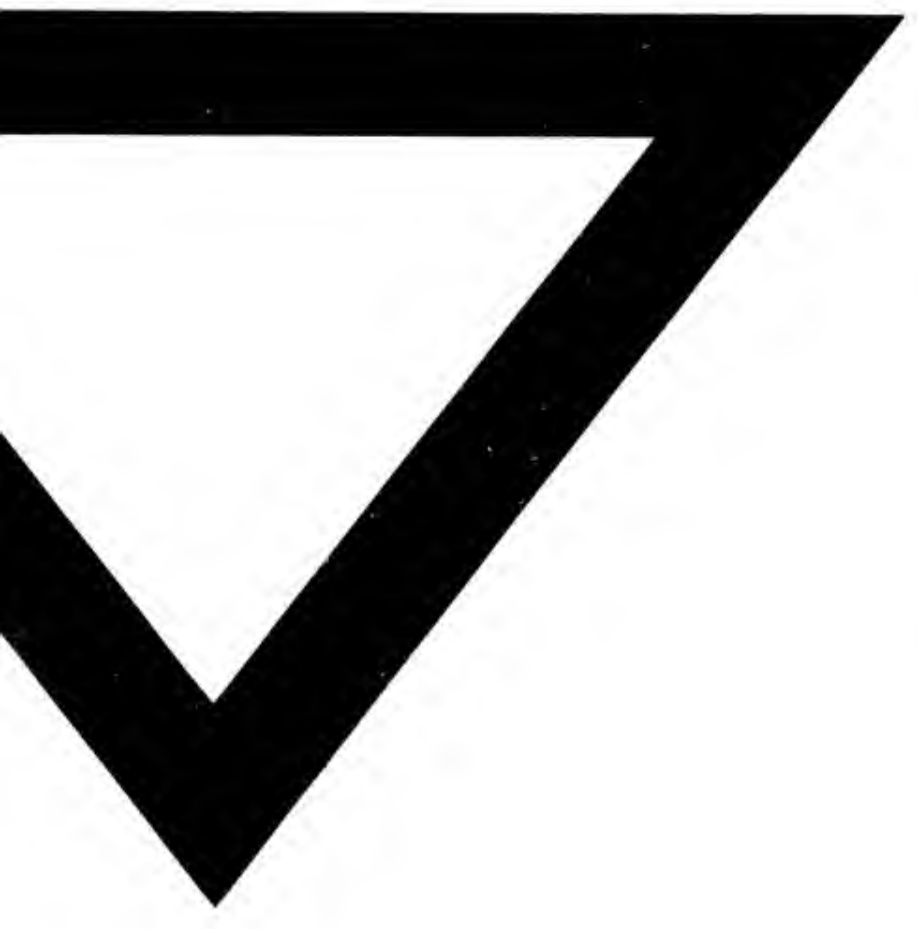

